\title{
Sale Boulot
}

Uma janela sobre o mais colossal trabalho sujo da história

\section{CAPÍTULO DO LIVRO}

Q novo tempo do mundo e outros estudos sobre a cra da emergência 


\section{Sale Boulot}

Uma janela sobre o mais colossal trabalho sujo da história

C A PÍTULODOLIVRO

O novo tempo do mundo e outros estudos sobre a era da emergềncia 
Categorias: Filosofia; Política; Estética; Arquitetura e Cidades; Artes Plásticas; Crítica da Cultura e Trajetórias. Cada categoria adota uma cor específica aplicada na capa do e-book.

\section{Subcoleções:}

E-books: livros, capítulos, prefácios, artigos e entrevistas (em formatos PDF, EPUB e MOBI/Kindle) - com obras em português, inglês, espanhol, italiano e francês.

Documentos: matérias de jornal, fotos e documentos históricos (em formatos PDF e JPEG)

Mídia: vídeos ou áudios de palestras, aulas e debates (em formatos MP3 e MP4) associados a um canal da coleção no YouTube.

Coordenação editorial: Pedro Fiori Arantes

Projeto Gráfico: Paula Astiz

\section{Dados Internacionais de Catalogação na Publicação (CIP)}

Arantes, Paulo Eduardo, 1942--

Sale boulot [recurso eletrônico] : uma janela sobre o mais colossal

trabalho sujo da história : uma visão no laboratório francês do

sofrimento social / Paulo Eduardo Arantes. -- São Paulo : [s.n],

2021.

ePUB. - (Coleção sentimento da dialética / coordenação Pedro Fiori Arantes)

\section{ISBN 978-65-00-34973-3}

1. Holocausto judeu (1939-1945). 2. Sofrimento - Aspectos sociais. 3. Justica social. 4. Trabalho - Aspectos sociais. I. Arantes, Pedro Fiori, 1974-. II. Título. III. Série.

CDD 331.01

Elaborado por Cristiane de Melo Shirayama - CRB 8/7610

DOI: https://doi.org/10.34024/9786500349733

\section{(c) (1) $(\Theta \Theta$}

Esta obra tem licença Creative Commons internacional 4.0 http://creativecommons.org/licenses/by-nc-nd/4.0/

Publicado originalmente como capítulo em:

Revista Tempo Social, Departamento de Sociologia USP, v.23 n. 1, e incluído posteriormente no livro o novo tempo do mundo e outros estudos sobre a era da emergência. São Paulo, Boitempo, 2014.

\section{Sentimento da Dialética}

UM ENCONTRO COM A OBRA DE OTÍLIA E PAULO ARANTES

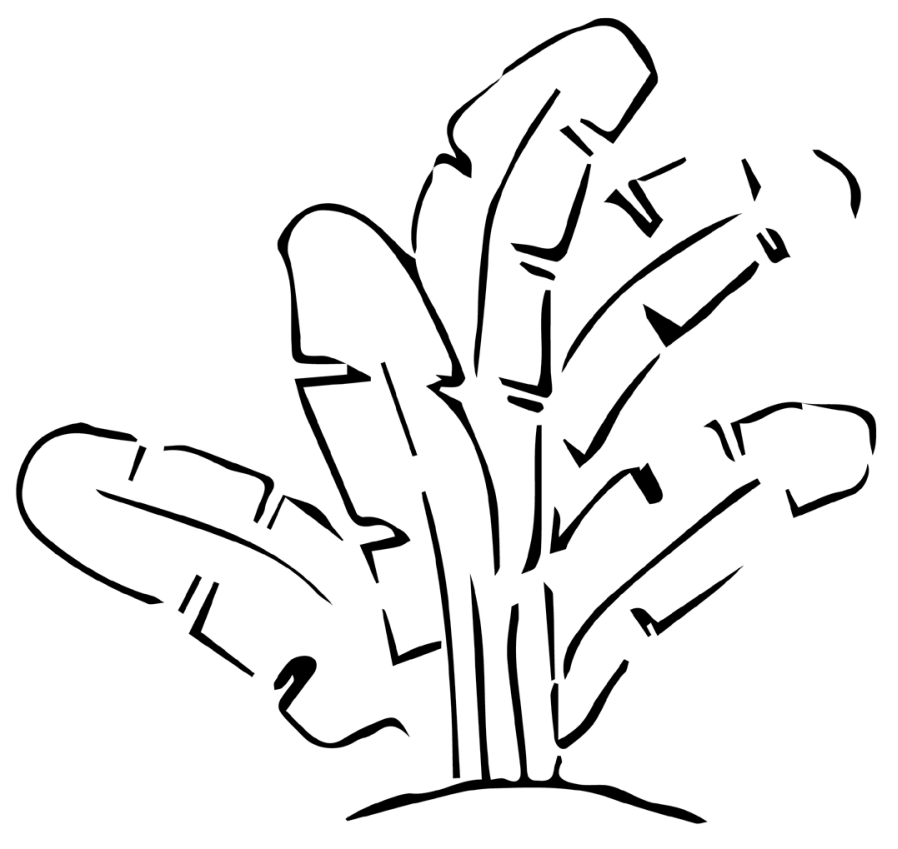




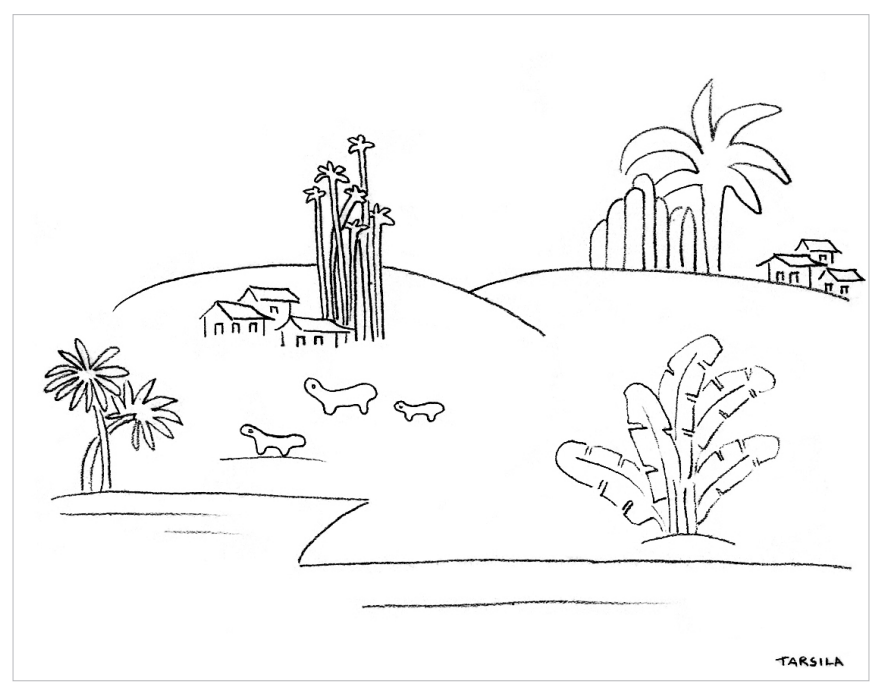

Tarsila do Amaral. Paisagem antropofágica - I, 1929 c - lápis s/ papel, 18,0 x 22,9 cm. Coleção Mário de Andrade. Coleção de Artes Visuais do Instituto de Estudos Brasileiros USP. Reprodução gentilmente cedida pela família e IEB USP.

O novo tempo do mundo exige dos intelectuais responsabilidades que lhes são intrínsecas: a de tornar a força das ideias parte do movimento de entendimento e transformação do mundo. Os filósofos Otília Beatriz Fiori Arantes e Paulo Eduardo Arantes cumprem, juntos, há mais de 50 anos, a tarefa da crítica como intelectuais públicos atuantes, transitando entre diversas áreas das humanidades e da cultura, em diferentes audiências e espaços de formação. A coleção Sentimento da Dialética é um lugar de encontro com a obra de Otília e Paulo Arantes e reafirma o sentido coletivo da sua produção intelectual, reunida e editada em livros digitais gratuitos. É um encontro da sua obra com um público cada vez mais amplo, plural e popular, formado por estudantes e novos intelectuais e ativistas brasileiros. É também um encontro da sua obra com o movimento contemporâneo em defesa do conhecimento livre e desmercantilizado, na produção do comum e de um outro mundo possível. 
SALE BOULOT

Uma janela sobre o mais colossal trabalho sujo da história (Uma visão no laboratório francês do sofrimento social) 


\section{SALE BOULOT}

\section{Uma janela sobre o mais colossal trabalho sujo da história}

\section{(Uma visão no laboratório francês do sofrimento social)}

1.

O visionário em questão é Christophe Dejours, estimulado por sua vez, nesta visão dissonante, por um estudo pioneiro de Joseph Torrente, também psiquiatra, que na época estava concluindo uma tese sobre o sofrimento no trabalho. Relendo hoje o ensaio de Dejours sobre a incrível atenuação das reações de indignação, cólera e mobilização coletiva em favor de justiça e solidariedade social - ainda não se extinguiu a memória da luta de classes no país que a inventou -, ao passo que se aprofundavam não menos escandalosamente as manifestações de franca indiferença diante da descomunal desgraça semeada por uma nova máquina de guerra econômica, impressiona sobretudo um inusitado lance de audácia no coração do argumento, que na época passou despercebido e até hoje, salvo enga-

* Publicado originalmente em 2011 na revista Tempo Social, Departamento de Sociologia USP, v.23 n. 1, e incluído posteriormente no livro O novo tempo do mundo e outros estudos sobre a era da emergência, São Paulo, Boitempo, 2014 
no, continua na sombra1. Ou por outra, onde havia um tremendo achado de percepção histórica, enxergou-se apenas o despropósito de uma assimilação obviamente disparatada, a saber: do Neoliberalismo vencedor (maiúscula para a novidade do fenômeno, verdadeira ruptura de época e não mera restauração que além do mais a crise de 2008 teria abortado) ao antigo sistema nazi de violência, nada mais nada menos. Tomado ao pé da letra, uma analogia sem pé nem cabeça, por mais calamitoso que seja o horror econômico do nosso tempo. É bem verdade que esse amálgama irrefletido costumava ser disparado a três por dois: fora tão acachapante a rendição, tamanha a perplexidade de se passar a viver numa sociedade sem oposição nem futuro alternativo visível (o novum chinês reside na mistura macabra de dois velhos ingredientes, capitalismo e ditadura burocrática) que parecia mesmo pairar no ar algo de terrivelmente "totalitário", embora ninguém estivesse de acordo nem mesmo quanto à real natureza dos "totalitarismos" históricos, para não falar no próprio conceito, que o condomínio da Guerra Fria desmoralizara até o osso.

Também é verdade que não economizou provocações sugerindo tamanha enormidade. A mais acintosa delas: revolver, sem maiores considerandos, uma ferida nacional que até hoje não cicatrizou, a Colaboração com o ocupante nazi, ela mesma desdobramento de uma estranha derrota, como dizia no seu tempo Marc Bloch. Quem tolera o intolerável - por assim dizer tricotando enquanto se assiste ao desfile da charrette dos condenados ao aterro sanitário social, como nos tempos em que se vivia sem maiores états d'âme à sombra da guilhotina - , sob a alegação meio

1. Ch. Dejours, Souffrance en France: la banalisation de l'injustice sociale, Paris : Seuil, 1998. sonsa de que a nova e intratável aflição econômica é menos uma flagrante violência social do que mero efeito colateral de uma dominação sem sujeito, não apenas consente mas colabora, mas agora na acepção infamante com que se designava os cúmplices do inominável, pouco importa se por rasteiro oportunismo ou por vileza política. A sugestão historicamente descabida de cumplicidade não se refere portanto à conivência trivial num malfeito, nos termos da responsabilização individual segundo o direito comum. A colaboração propriamente dita (anacronismo incluído, por certo cum grano salis), ontem e hoje, só ocorre (mais uma volta no parafuso da ênfase máxima) quando o Mal — seja lá o que isso queira dizer, por enquanto - se erige em sistema, convertendo-se em norma de todo ato civil. Para ir direto ao ponto de nosso autor, o "mal" se reapresentaria hoje como um sistema de gestão, como um princípio organizacional: das empresas, dos governos, de todas as instituições e atividades, em suma, que, organizadas segundo esse mesmo princípio, foram se convertendo em centros difusores de uma nova violência, e incubadoras de seus agentes, os ditos colaboradores do nosso tempo. Na definição adotada por Dejours, e que não vem ao caso esmiuçar agora, faire le mal é infligir a alguém um sofrimento indevido, aliás um ato de mão dupla, pois essa mesma aflição respinga em seus perpetradores, posições patológicas à parte. Reconhecidamente uma variante da ideia platônica acerca do sofrimento moral que causa a injustiça naquele que a comete de caso pensado, sabendo que se trata de uma injustiça inseparável da consciência do malfeito. Daí o caráter epidêmico do sintoma. Sob a pressão da concorrência interiorizada em seu nível histórico máximo, de um jeito ou de outro todos acabam arregimentados para o serviço da "colaboração", que não funciona se não insensibilizar seus agentes através 
de mil expedientes e armadilhas defensivas. Comparado a esse grandioso sistema de colaboração stricto sensu, o ciclo fordista-taylorista anterior poderia ser revisto como um regime de alienação em tempo parcial.

Voltando ao trilho das comparações insensatas, colaboração por colaboração, Ch. Dejours e seu colega J. Torrente repassaram o suficiente da melhor historiografia do Terceiro Reich, em particular sobre o Holocausto, especialmente na sua vertente mais sóbria, dita "funcionalista", por oposição à gesticulação melodramática dos "intencionalistas", adeptos da lógica motivacional de uma causa eliminacionista única do genocídio. De acordo com a revisão estruturalista da Shoah, "Hitler estabeleceu o objetivo do nazismo: livrar-se dos judeus e, acima de tudo tornar o território do Reich judenfrei, isto é, livre de judeus, mas sem especificar como isso seria alcançado"2. A princípio no intuito de

2. Michael Marrus, The Holocaust in History citado por Zygmunt Bauman, Modernidade e Holocausto (Rio de Janeiro: Zahar, 1998, p. 41), que também remete ao estudo inovador de Karl Schleunes, de 1970, The Twisted Road to Auschwitz. Um ano depois, Raul Hilberg publicava sua monumental Destruição dos Judeus Europeus (hoje na terceira edição revista e ampliada, Yale), que consultei na última edição francesa de 2006 (La destruction des juifs d'Europe, Paris: Gallimard, Folio/Histoire, 3 vols.). Não por acaso Christopher Browning dedicaria a Hilberg seu notável Ordinary Men, de 1992, que também li na tradução francesa prefaciada por Vidal-Naquet, Des hommes ordinaires: le $101^{e}$ batallion de réserve de la police allemande et la Solution Finale en Pologne (Paris: Taillandier, 2007). Como se verá, Hilberg e Browning deram régua e compasso para a "visão" de Torrente desenvolvida por Dejours, como ele próprio assinala em nota à pg 176 do livro que estamos relendo por este ângulo específico. Não tive acesso ao doutorado de Torrente, La souffrance au travail: entre servitude et soumission (CNAM, 1999). Em compensação pude ler seu estudo na Revue d'histoire de la Shoah (n.175), "Travail et banalité du mal", no qual desenvolve o conceito de "trabalho do mal", cuja origem faz remontar ao ponto de vista adotado por Hilberg em sua espantosa reconstituição, ao considerar "o fenômeno massivo da destruição dos judeus como um trabalho cuja meta era o genocídio": é precisamente este trabalho que denominará trabalho do mal. No presente artigo, entretanto, acompanho o roteiro traçado por Dejours, notadamente no que se refere ao termo de comparação "neoliberal", até o momento em que cruza o caminho mais específico de Torrente, compondo então um só argumento. recortar a novidade da colaboração de hoje sobre o pano de fundo histórico de uma constatação elementar: a estrada sinuosa que conduziu à exterminação física dos judeus na Europa, traçada ao sabor de "radicalizações cumulativas" (nas palavras de um outro "estruturalista", Hans Mommsen), "não foi concebida na visão singular de um monstro alucinado nem foi uma opção ponderada de líderes ideologicamente motivados", ainda na recapitulação de Bauman, ou no resumo desta mesma historiografia por Robert Paxton, a saber, que as fantasias assassinas de um punhado de hierarcas nazis teriam permanecido apenas fantasias não fosse o empenho dos "milhares de subordinados cuja participação nas ações cada vez mais violentas contra os judeus da Europa fez com que o mecanismo funcionasse ${ }^{3}$.

Como assinalado, uma das pedras angulares dessa nova tradição historiográfica foi lançada por Raul Hilberg, que ao elencar todas as providências organizacionais que culminaram na passagem ao ato da Solução Final — definição fatal de uma entidade apartada "indivíduo-judeu": a seguir "marcado" pela estrela amarela; ato contínuo, expropriado; mais adiante, emparedado num gueto; deportado e enfim assassinado - , de fato demonstrou que a máquina nazista de extermínio não seria nada sem essa terrível capacidade de agenciar milhões de seres humanos e extrair deles, como notaram por sua vez Dejours e Torrente, uma paradoxal coordenação e cooperação de inteligências e subjetividades singulares. Sem a qual, diga-se de passagem, tampouco Hannah Arendt, que se escora amplamente nas observações luminosas e estarrecedores do relato de Hilberg, teria chegado a encarar como se sabe a

3. Robert Paxton, A anatomia do fascismo, São Paulo: Paz e Terra, 2007, p. 260 . 
famigerada banalidade do mal, mostrando do que é capaz um cidadão respeitador das leis como Eichmann, em cuja cabeça povoada de frases feitas, a seu ver funcionava, entre outras engrenagens diligentemente lubrificadas, um gigantesco entroncamento ferroviário, afinal fora aquele pequeno personagem que pusera nos trilhos a questão judaica. Restaria saber o que pensava a combativa categoria dos ferroviários que operavam diretamente a malha daquela logística infernal, além do mais em plena guerra e raramente falhando na entrega. Não faltam historiadores que incluiriam sem hesitar nossos cheminots - para continuarmos no exemplo, em francês só para lembrar que a Ocupação não passou sem sabotagens no setor que depois renderam filmes catárticos - entre os beneficiários de Hitler, notando que um peculiar Welfare de exceção comprou o consentimento do povo alemão. Alguns chegam até a sustentar que, ao contrário do lugar comum segundo o qual a ralé hitlerista nada mais seria que a guarda pretoriana do grande capital monopolista, o sistema nazi transferiu riqueza e renda dos possuidores de alguma coisa para os sem-nada, sendo que 4/5 dos alemães, até a capitulação, não pagavam impostos de guerra diretos, está claro que o conjunto da obra alimentado pela aniquilação econômica das sub-raças que parasitavam o povo-nação. Este mesmo bom povo popular de uniforme, mal começada a guerra, saqueou a Europa anexada e sangrada. Numa palavra, a colaboração da gente comum no genocídio resultou de uma gigantesca barganha em termos de benefícios materiais, comprava-se diariamente sua satisfação ${ }^{4}$.

4. Cf. John Connelly "It never occurred to them", London Review of Books, de 27/08/2009. Resenha do livro de Götz Aly, Hitler's Beneficiaris: How the Nazi Bought the German People, London: Verso, 2007. Ver ainda Robert Gellately, Backing Hitler: Consent and Coercion in Nazi Germany, NY, 2001.
Todavia algum ingrediente mais específico deveria ser procurado nessa operação de compra e venda, não se tratava de mero consentimento na dominação, mas de cooperação num massacre moralmente repugnante. Como resume o próprio Hilberg, "a máquina de destruição não era estruturalmente diferente da sociedade alemã organizada como um todo. A máquina de destruição era a comunidade organizada num dos seus papéis especiais"5.

A chave de todo esse enigma, nossos dois autores irão buscar no modus operandi desta participação sinistramente empenhada. Aqui o salto mortal: guardadas todas as proporções, tudo se passa como se estivéssemos interessados em identificar o equivalente contemporâneo daquela zona cinzenta à qual Primo Levi consagrou um dos seus mais impressionantes capítulos. Um lembrete para ajudar a memória:

“É ingênuo, absurdo e historicamente falso julgar que um sistema infernal, como o nazismo, santifique suas vítimas: ao contrário, ele as degrada, assimila-as a si, e isto tanto mais quanto elas sejam disponíveis, ingênuas, carentes de uma estrutura política ou moral. Muitos sinais indicam que parece ter chegado o tempo de explorar o espaço que separa (não só nos Lager nazistas!) as vítimas dos opressores, e de fazê-lo com a mão mais ágil e o espírito menos turvo do que se fez, por exemplo, em alguns

(ed. brasileira: Apoiando Hitler: consentimento e coerção na Alemanha nazista, Rio de Janeiro: Record, 2011.

5. Apud Bauman, op. cit. p. 27. 
filmes. Só uma retórica esquemática pode sustentar que aquele espaço seja vazio: jamais o é, está coalhado de figuras torpes ou patéticas (às vezes possuem as duas qualidades ao mesmo tempo) que é indispensável conhecer se quisermos conhecer a espécie humana" ${ }^{6}$.

Essa "zona cinzenta, com contornos mal definidos, que ao mesmo tempo separa e une o campo dos senhores e dos escravos", é o espaço mesmo da colaboração que estamos procurando redescrever - quer dizer, nossos dois autores. Como sabido, é naquele capítulo espantoso que Primo Levi estudará a classe híbrida dos prisioneiros-funcionários que a rigor tocavam os campos da morte, detendo-se de modo particular nos Sonderkommandos - "ter concebido e organizado esses esquadrões especiais foi o delito mais demoníaco do nazismo", um "abismo de maldade" no coração da zona cinzenta.

Pois novamente guardadas todas as proporções, são tais "abismos de maldade" que Ch. Dejours está convencido de ter redescoberto no atual ciclo de intensificação do sofrimento social no e pelo trabalho. E como se isso não bastasse, a seu ver é a surpreendente centralidade negativa do trabalho hoje que lança uma nova luz sobre o funcionamento daquela zona cinzenta sem a qual o nazismo não teria chegado à Solução Final. Como quem diz: agora que o tournant neoliberal revirou pelo avesso a sociedade contemporânea repovoando com novas combinações aqueles espaços supostamente vazios separando opressores e explorados, poderemos enfim atinar com a mola secreta do

6. Primo Levi, Os afogados e os sobreviventes, Rio de Janeiro: Paz e Terra, 1980, pp. 19-20. poder nazi. Foi portanto ao encarar por um outro ângulo — o dos mecanismos subjetivos da dominação - a loucura contemporânea do trabalho, logo no início do presente período, que Ch. Dejours pode perceber o que escapara à H. Arendt: que a fonte da banalização do mal é menos o vazio do pensamento, tão temido pelos gregos, do que o trabalho - que pode inclusive esvaziar o dito pensamento, cuja desnecessidade torna enfim a humanidade igualmente dispensável.

Mas de que trabalho se trata afinal? Não só o trabalho não desapareceu, como ao ser reorganizado pela nova racionalidade neoliberal, a percepção de sua proliferação destrutiva permitiu reencontrá-lo a todo vapor empurrando a mobilização total que culminou nos massacres administrativos nazistas. O vento novo que ainda sopra no livro de Dejours é que sua redefinição do processo de trabalho - entre tantas variantes, vamos reter apenas uma, ainda enigmática: o trabalho é o zelo - ilumina as duas épocas históricas sem amalgamá-las. Visto pelo ângulo da predação contemporânea do trabalho vivo, o que se observa no assim chamado mundo do trabalho é a operação de um tremendo laboratório de violência social, no qual se aprende a fazer experimentos extremos com a injustiça e a iniquidade. E vice-versa, por esse mesmo prisma podemos considerar que se não fosse pelo zelo, as fábricas nazistas da morte não poderiam operar.

Mas ao se deparar com a deixa de que precisava para redescrever a paisagem da zona cinzenta de um ponto de vista armado pela experiência do sofrimento social contemporâneo - depois de anunciar que chegou o tempo de explorar aquela "infame zona de irresponsabilidade" 
como a denomina Agamben ${ }^{7}$, se é verdade que ainda desejamos defender nossa alma quando uma provação análoga se apresentar novamente, Primo Levi acrescenta, mais simplesmente, ou se quisermos somente "nos dar conta daquilo que ocorre num grande estabelecimento industrial" - Dejours não se limitará, por isso mesmo, à analogia incontestável entre as entranhas monstruosas de Auschwitz e uma não menos descomunal planta industrial fordista, ou mesmo um corpo gigantesco de escritórios, devassado seja à maneira mítica de Kafka, seja ao modo hollywoodiano não menos sinistro dos filmes sobre o homem-organização americano da trégua keynesiana do pós-guerra. Assim, um ensaio como o de Z. Bauman não deixa de pagar tributo a essa dimensão irrecusável ao sugerir, não que a cultura burocrática da razão instrumental, como pode ser resumida a fusão entre capitalismo industrial e burocracia racional weberiana, tenha tornado o Holocausto uma fatalidade, mas sim que as regras de tal racionalidade indiferente aos fins são singularmente incapazes de evitar tais hecatombes, na medida mesma em que a sociedade é vista como um objeto de administração e portanto como algo a ser controlado, melhorado, refeito etc, numa palavra, "a atitude do jardineiro que divide as plantas entre aquelas cultiváveis, de que se deve cuidar, e as ervas daninhas a serem exterminadas"8. É inegável que o Holocausto só poderia ser concebido numa atmosfera como essa, bem como a teoria crítica de Bauman continua

7. Georgio Agamben, o que resta de Auschwitz, São Paulo: Boitempo, 2008, p. 31. Fica para outra ocasião a discussão do que vem a ser esse domínio, nas palavras do autor, "refratário a qualquer identificação de responsabilidade". E seu equivalente atual, é claro.

8. Modernidade e Holocausto cit., p. 37. devedora dessa mesma era da engenharia social do horror — "e também sugiro", continua com razão Bauman, "que foi o espírito da racionalidade instrumental e sua forma moderna, burocrática de institucionalização que tornaram as soluções tipo Holocausto não apenas possíveis mas eminentemente 'razoáveis', e aumentaram sua probabilidade de opção" - que no entanto mudou, dispensando totalmente sua carapaça burocrática (não à toa desmoronou o sistema soviético de dominação junto com seu homólogo capitalista), mas não a ponto de perder sua característica crucial, pelo contrário, essa continua escalando exponencialmente, a saber a capacidade de "coordenar a ação de grande número de indivíduos morais na busca de quaisquer finalidades, também imorais".

Não se trata de projeção retrospectiva, mas o fato é que Dejours e Torrente reconsideram aquele processo de banalização do mal uma vez ultrapassado o limiar de uma outra grande transformação que Polanyi não havia previsto. Na máquina de extermínio industrializado já não viram mais apenas o funcionamento burocrático, mas justamente o que permitiu que ela funcionasse de uma maneira tão pavorosamente eficaz, apesar da burocracia, de cuja racionalidade formal, segundo Weber, a acumulação capitalista não podia mais prescindir. Soubesse ou não o definir em termos conceituais, Primo Levi estava revelando na colaboração entre operadores num campo da morte a existência de um outro trabalho que não o fornecido por um sistema concentracionário de extração de mais-valia absoluta. Tratava-se com certeza de uma outra economia política. Depois de citar Eugen Kogon - "grande parte do trabalho imposto nos campos de concentração eram inúteis; ou era supérfluo ou era tão mal planejado que tinha que ser feito duas ou três vezes" - , e no intuito 
de sublinhar a atmosfera de loucura e irrealidade criada pela aparência desconcertante de ausência de propósitos que ofuscava o reconhecimento da realidade dos campos, Hannah Arendt foi das primeiras a notar, ainda no imediato pós-guerra de trauma e poeira nos olhos, que a incredulidade dos horrores estava intimamente associada à sua inutilidade econômica, ou de franca anti-utilidade, aliás o único escândalo aos olhos de um mundo estritamente utilitário ${ }^{9}$. Não era menos verdade, todavia, como ainda relembraria mais tarde a mesma Hannah Arendt, que "a cooperação entre a SS e os empresários era excelente, mas quanto às condições nas fábricas, a ideia era, claramente, matar por meio do trabalho"10. Pois o trabalho que está nos interessando - não custa antecipar, ou reparar - é justamente o da organização da morte atroz pelo trabalho. Para ser mais exato, como dirá Joseph Torrente, referindo-se, como veremos extensamente, à invenção nazi da produção em massa do crime como um trabalho, trata-se, nada mais nada menos, da "exploração ilimitada dos recursos da submissão defensiva"11. Mas aqui já estamos com um pé em nosso tempo.

Voltando à tentativa de identificação desse "trabalho" (e assim retirar-lhe as aspas), lembrando mais uma vez que ele só seria plenamente reconhecido à medida que se cristalizava a percepção de que o novo mundo do trabalho moldado pela racionalidade neoliberal domi-

\section{Cf. Origens do totalitarismo, São Paulo: Cia das Letras, 2004, p. 495.}

10. Eichmann em Jerusalém, São Paulo, Cia das Letras: 1999, p. 93.

11. “Travail et banalité du mal" cit., p. 175 nante ${ }^{\mathbf{1 2}}$ se transformara num imenso campo de experimentação e difusão da crueldade social, descontada é claro toda a cosmética clean da acumulação dita flexível - por David Harvey, entre outros, como se sabe. Não é que não houvesse alienação e violência no período anterior do trabalho repetitivo coagido pelos cronômetros. Os estragos afetivos e cognitivos produzidos pelo fordismo não deixavam de favorecer, na mesma escala gigantesca das velhas plantas, a emergência, defensiva e ofensiva, da compulsividade da violência. A coisa toda muda nos contextos organizacionais que desarticulam a linha de montagem fordista: com as condutas iníquas que então se generalizavam, o problema da alienação se reformula por inteiro, adotando inclusive a altamente enfática e ambígua semântica do mal - adormecida desde o escândalo político e moral provocado pelo caso Eichmann segundo $H$. Arendt, e ressuscitada como névoa de guerra social a partir dos anos $70^{13}$, de tal sorte

12. Como é a segunda ocorrência dessa expressão, seria o caso de desbanalizála desde já esclarecendo a acepção precisa em que está sendo empregada, pelos seus formuladores originais é claro, Pierre Dardot e Christian Laval, justamente interessados em problematizar a novidade do Neoliberalismo, menosum receituárioideológico rudimentar ou uma política macroeconômica (o que também é, porém, subsidiariamente), do que fundamentalmente uma racionalidade que tende a estruturar e organizar não somente a ação dos governos mas também, ou sobretudo, a conduta dos governados. Cf La nouvelle raison du monde: essai sur la societé néoliberale (Paris: La Découverte/Poche, 2010). A novidade do neoliberalismo enquanto atividade de «governo» das condutas (não confundir com a instituição estatal) é que ela não se define nem contra nem a despeito da liberdade, mas através da liberdade de cada um, no sentido de que se conformem por si mesmos a certas normas. Sem precisar forçar a mão, não é muito difícil reconhecer neste arcabouço os traços contemporâneos de uma livre submissão defensiva, nos termos da nota anterior, quer dizer a pista por onde escorrerá toda a sujeira do trabalho.

13. Se sobrar espaço, evoco brevemente esta derradeira intriga da finada Ideologia Francesa num eventual epílogo. Se não, fica para outra. Numa palavra, o espantalho catastrófico do mal, de tanto ser agitado preventinamente, acabou sofrendo uma segunda e mais prosaica banalização. Já o "mal" que comparece no discurso da psicodinâmica das situações de 
que é o próprio trabalho gerador de infelicidade, alienação e doença mental, que fornece a chave explicativa das estratégias de defesa entranhadas nos "comportamentos de aceitação do mal, para se adaptar ao sofrimento acarretado pelo medo" - medo esse, sabidamente, o principal combustível das tecnologias neoliberais de poder. Pois é justamente a experiência (clínica no caso) do mal como injustiça infligida aos outros como forma "banalizada" da gestão neoliberal do trabalho que não só permite, mas obriga politicamente a reinterpretar o flagelo nazi como uma mobilização para o massacre que seria, agora sim, impensável, sem essa mise au travail de todo um povo: só o trabalho tornou possível organizar essa conduta de massa em proveito do horror. Primo Levi teria revelado uma zona cinzenta ainda mais recôndita em que o trabalho e o mal seriam coextensivos, quando mais não seja porque é através da relação do trabalho enquanto relação social de desigualdade que nos confrontamos primordialmente com a dominação e a experiência da injustiça. Em nome do trabalho, sempre se poderá valorizar uma desgraça. Este o segredo de toda "colaboração".

trabalho - como é o caso da "visão" que nossos dois autores tiveram ao abrir uma outra janela sobre a Shoah — está enraizado na realidade vivida (e descrita) do sofrimento ligado à dominação, à violência e à injustiça, ancorado portanto numa dimensão da centralidade política do trabalho até então desconhecida. Cf Emmanuel Renault, Souffrances sociales (Paris: La Découvert, 2008) e Patrick Coupechoux, La déprime des opprimés : enquête sur la souffrance psychique en France (Paris : Seuil, 2009). Não por acaso, toda a última grande onda contestária no outono de 2010 na França pode e deve ser lida também nesta chave. Cf Danièle Linhart, "Métro, boulot, tombeau",

Le Monde Diplomatique, novembro 2010; Pierre Dardot e Christian Laval,

"Le retour de la guerre sociale", Carré Rouge, 2010.

\section{2.}

A certa altura de sua argumentação - como explicar que "pessoas de bem" se deixem arregimentar para o exercício do mal como princípio organizacional, como princípio sistêmico de gestão de empresas e governos regidos pela mesma racionalidade que anima os novos controles capitalistas -, Ch. Dejours temendo o intrincado cipoal envolvendo a simples menção do "mal" como conceito manejável com a ênfase metafísica que se sabe desde que os campos de extermínio tornaram possível o impossível e o mal absoluto um fato histórico, e sem desconhecer portanto a circunstância fatal de que está falando no rastro de Auschwitz, propõe uma surpreendente equivalência, que sem ser conceitual, não é meramente vocabular: a rigor, o mal com o qual estamos voltando a nos defrontar, e que se distingue pela capacidade de mobilizar vontades, em princípio refratárias, nada mais é do que em linguagem coloquial se chamaria banalmente de trabalho sujo. No limite, a clínica do trabalho é de fato uma clínica do sale boulot - um inventário analítico das estratégias defensivas que asseguram a sobrevivência psíquica de quem, no sistema contemporâneo de empresas, vai fundo no "trabalho sujo", sem, no entanto, abrir mão da recompensa moral pelo dever cumprido. Aliás, complicando ainda mais as coisas, a simples sobrecarga semântica da expressão sale boulot sugeriria a existência de uma dimensão oculta do próprio trabalho ao longo da qual se teceria esta aliança tenebrosa com o mal.

Não penso estar me enganando demais se disser que essa genealogia do sale boulot, a conexão fatal entre trabalho sujo e banalização do mal, tenha ocorrido a $\mathrm{Ch}$. Dejours relendo o capítulo de Primo Levi sobre a "zona 
cinzenta". Ela está povoada de "colaboradores", cuja atividade sinistra é espontaneamente descrita no registro do "trabalho", invariavelmente qualificado de "sujo", por razões óbvias, mas por outro lado não tão óbvia assim. Algumas oposições são imediatas: aos Trawnicki (lumpen recrutado nas regiões fronteiriças da União Soviética), por exemplo, sempre se confiam "as tarefas mais sujas" nos momentos da carnificina direta de judeus e comissários comunistas, sem que jamais sejam empregados em combate. Além da oposição combatente regular/massacradores, mais ou menos emporcalhados pelos respingos, uma outra distinção não menos evidente refere-se à "sujeira" - figurada e literal - de vítimas impuras e poluídas, cujo manuseio, antes, durante e depois do "serviço", só poderia ser nauseante e repulsivo. Referindo-se à fauna pitoresca dos prisioneiros "sem graduação", chama-os de "funcionários de escalão inferior", executando "funções terciárias", acrescentando que em pouco tempo desenvolviam uma mentalidade tipicamente corporativa que os levava a defender com energia seu "posto de trabalho". Executado por pobres diabos como os demais, seu concurso para o crime foi mínimo enquanto pesava sobre eles o máximo de coerção: trabalho inócuo, no geral inventado do nada por um pouco de sopa a mais, não era propriamente sujo embora o fosse. Havia, portanto, gradações. O grau máximo cabe por certo aos Sonderkommandos, cujo "ofício" Primo Levi descreveu como um "trabalho", ou melhor, como a parte do trabalho "justamente a mais suja", que os SS delegavam às próprias vítimas, a "tarefa atroz" do massacre quotidiano: a triagem sinistra posterior e a gestão dos fornos crematórios. O mais impressionante é que os próprios integrantes dos Esquadrões Especiais foram os primeiros a definir sua queda naquele abismo de maldade como trabalho: conforme um sobrevivente declarou e Primo Levi transcreveu, "ao fazer este trabalho, ou se enlouquece no primeiro dia, ou então se acostuma". E transcreveu justamente na linguagem do trabalho. Se Ch. Dejours e J. Torrente estão certos, dá para imaginar de que modo o simples fato de encarar "aquilo" como trabalho contribuiu decisivamente para acionar nossa “perigosa capacidade de acostumar-se às coisas", na fórmula emprega por Hans Adler ao descrever os processos de aprendizado adaptador nos campos de Theresiensta$\mathrm{dt}^{14}$. Um outro testemunho não menos estarrecedor, recolhido pelo mesmo Primo Levi, evoca

"uma partida de futebol entre SS e Sonderkommando, entre uma representação dos SS de guarda no forno crematório e uma representação do Esquadrão Especial. À partida assistem outros SS e o resto do esquadrão, torcendo, apostando, aplaudindo os jogadores, como se a partida de desenrolasse não diante das portas do inferno, mas num campo de aldeia"15.

O comentário de Agamben - no qual se entrelaçam os motivos benjaminianos bem conhecidos da exceção e da norma, cuja fusão infernal exige desde sempre uma parada de emergência - vale a transcrição em mais de um ponto. Nos ateremos ao nosso:

14. Citado por Barrington Moore Jr, Injustiça: as bases sociais da obediência e da revolta, São Paulo: Brasiliense, 1987, p. 107.

15. Primo Levi, Os afogados e os sobreviventes cit., p. 29. 
“essa partida poderá parecer a alguém como se fosse uma breve pausa de humanidade em meio a um horror infinito. Aos meus olhos, porém, como aos das testemunhas, tal partida, tal momento de normalidade, é o verdadeiro horror do campo (...) Aquela partida nunca terminou, é como se continuasse ainda, ininterruptamente, ela é o emblema perfeito e externo da 'zona cinzenta' que não conhece tempo e está em todos os lugares (...) Dela também provém a nossa vergonha, de nós que não conhecemos os campos, que, mesmo assim, assistimos, não se sabe como, àquela partida que se repete em cada partida dos nossos estádios, em cada transmissão televisiva, em cada normalidade quotidiana. Se não conseguirmos entender aquela partida, acabar com ela, nunca mais haverá esperança"16.

Com aspas, é claro, não menos revelador do eixo sobre o qual gira todo o grotesco da cena de colegas "unidos pelo vínculo imundo da cumplicidade imposta", é o fato de Primo Levi apresentar aquele intervalo de normalidade grotesca como "uma pausa de trabalho", no trabalho sujo evidentemente, como o "tempo livre depois de uma jornada estafante se desincumbindo de algum sale boulot.

Numa palavra - curiosamente proferida por um inocente sociólogo americano, embora eminente em sua profissão, num longínquo artigo de 1962: contra o povo judeu, mas não só, a Alemanha Nazista “operou o mais colossal

16. Agamben, O que resta de Auschwitz cit., p. 35. trabalho sujo da história"17. O duplo achado dessa fórmula fulminante se deve a Zygmunt Bauman, que no entanto não sabe bem o que fazer com ela, salvo ilustrar o pouco que a sociologia conseguiu dizer sobre o Holocausto - de fato um certificado de falência ${ }^{\mathbf{1 8}}$. Relendo-se a íntegra do artigo em questão, verifica-se que de fato o Prof. Hughes sinceramente escandalizado com o que viu e ouviu numa viagem a Alemanha em 1948 - está à procura da melhor tecnologia de planejamento social para inibir a conjunção de circunstâncias que levaram uma imensa maioria de boas pessoas, que efetivamente não sujaram as mãos, a consentir no horror, por sua vez perpetrado por outros incontáveis homens comuns, igualmente civilizados. Seja como for, não é fácil atinar com as razões que levaram a tamanho acerto. Afinal o que teria inspirado aquele incrível golpe de vista em nosso remoto sociólogo ao juntar sem essa mais aquela a presumida personificação do Mal Absoluto, impunível e imperdoável, como já se disse, e um reles, embora ciclópico, "trabalho sujo"? O instinto da língua, quem sabe, acrescido da familaridade infusa com a fórmula americana do filme noir. Quando se fala em dirty work, a referência imediata é um serviço no geral penoso, ou simplesmente à margem da legalidade ordinária, que alguém presta a um terceiro, via de regra em posição de comando, ou pelo menos revestido da autoridade suficiente para proclamar sua nenhuma disposição de se desincumbir da tarefa, relegada assim à dúbia categoria em questão, a da "sujeira”, de qualquer modo necessária

17. Everett C. Hughes, "Good People and Dirty Work” Social Problems, verão de 1962, pp. 3-10.

18. Modernidade e Holocausto cit., p. 21. 
ao andamento geral das coisas. Por certo o instinto da linguagem dos filmes B, mas também uma peculiar percepção de época. A edição que pude consultar reapresentava o artigo acompanhado por um preâmbulo de atualização, não assinado, e datado possivelmente do fim dos anos 60. No ar, um outro motivo de escândalo, o fato de que os "trabalhadores sociais" - de educadores a assistentes sociais atuando em zonas de relegação em que a poeira da agitação por direitos civis ainda não havia assentado, passando curiosamente por agentes penitenciários - estavam sendo empurrados para a área de sombra, ao que parece reservada ao dito trabalho sujo, ou seja, profissões concebidas para ajudar ou cuidar estavam sendo redesenhadas para vigiar ou punir, pior, esses "dirty workers", que volta e meia se ressentiam da missão duplamente degradante, se viam apanhados e comprimidos entre seu alvo recalcitrante e uma classe média comanditária que não só lhes ordenava o trabalho como exigia que o fizessem em silêncio - entre outros serviços: "keep the colored out of our way".

Agora, pensando bem e divagando um pouco em voz alta, porém sempre no encalço do vínculo genealógico revelado uma primeira vez pelos massacres administrativos do Terceiro Reich, uma segunda vez, pela gestão do trabalho no novo capitalismo, um nexo não convencional entre o trabalho portanto dito sujo e tudo aquilo que o mal pode fazer, como simplesmente fazer mal, não seria o caso de estarmos nos defrontando com uma derradeira e original figuração de algo como um "arcaico ato de despotismo", que na antiga visão de Adorno e Horkheimer encerrou o ciclo originário do nomadismo através da violência de uma usurpação que institui o privilégio de um grupo social se fazer substituir permanentemente por outros membros da sociedade na execução de tarefas desde então socialmente distribuídas? A dominação se mediria então por esse poder, proprietário e sedentário, de pôr alguém para trabalhar no seu lugar ${ }^{19}$. Basta imaginar um pouco o gênero do trabalho a que estão condenados os intocáveis em uma sociedade de castas, para entender tal privilégio (que pode ser igualmente o de uma camarilha com poder de polícia em uma sociedade burocrática) como a capacidade de impor, ou simplesmente passar para a frente, o fardo do trabalho sujo. Tudo se passa como se aquele ato despótico originário houvesse simplesmente instituído o trabalho como trabalho sujo. Num certo sentido, variando um outro tema dos mesmos teóricos, também se poderia vislumbrar no esforço de autoconservação no seu estágio histórico de fim em si mesmo, a matriz do trabalho sujo por excelência. Na medida é claro, em que o fascismo finalmente se apresentou, na fase pós liberal do capitalismo, como a chave conclusiva de toda a história como história da dominação. Mas a essa altura de nossa digressão, seria preciso lembrar que só poderíamos sustentar a nota enfiando o trabalho, sujo ou não, na camisa de força da exclusiva ação instrumental. Segundo o roteiro delineado pela clínica do trabalho, uma restrição fatal: simplesmente não poderíamos compreender porque só o trabalho teve o condão de transformar homens comuns em "corvos de forno crematório".

Por contraste, seria o caso de voltar ao capítulo conclusivo de Zigmunt Bauman, que vai justamente na direção oposta, embora no âmbito da mesma Teoria Crítica. O

19. A citação e o comentário, como qual obviamente tomo algumas liberdades, se encontram em Axel Honneth, The Critique of Power, Cambridge: The MIT Press, 1993, pp. 49-50. 
que há de chocante no documentário de Lanzmann sobre a Shoah? Qual é a terrível, humilhante verdade que desfila na interminável agonia das muitas horas de projeção do filme?

"Quão poucos homens armados foram necessários para matar milhões. Espantoso como estavam amedrontados aqueles homens armados, a que ponto conscientes da fragilidade de seu domínio sobre o gado humano. Seu poder assentava sobre condenados que viviam num mundo de faz-de-conta (...) Nesse mundo, a obediência era racional, a racionalidade era a obediência (...) Mas para fundar sua ordem apenas no medo a SS precisaria de mais horas, braços e dinheiro. A racionalidade era mais eficiente, mais fácil de obter e mais barata. E assim para destruí-la, os SS cultivavam cuidadosamente a racionalidade das vítimas" ${ }^{20}$.

Conversão mútua entre racionalidade e obediência - sempre se poderia acrescentar, na linha da imbricação entre razão e autoconservação —, devidamente instituída no momento em que entra em cena a dependência mediada pelo trabalho, entendido como a atividade daqueles que perderam a liberdade ou que de algum modo foram subjugados $^{21}$. O que resta do Holocausto é assim a revela-

20. Modernidade e Holocausto cit., pp. 231-232.

21. "Em Shoah, Lanzmann mostra um sobrevivente que conseguiu fugir de Treblinka e se lembra que, quando o gás diminuía nos alimentadores das câmaras, membros do Sonderkommando tinham suas rações de comida suspensas e, como não eram mais úteis, estavam ameaçados de extermínio. Suas perspectivas de sobrevivência renasciam quando novos grupos judaicos eram recolhidos e carregados nas trevas para Treblinka" (Ibidem, p. 230). ção, menos da banalidade do mal, do que de sua racionalidade, entendida como adequação formal e meramente subjetiva entre meios e fins. Por isso o mal não precisa de seguidores entusiasmados, basta o cálculo pulsional da autopreservação. Apostando na prevalência mortal desse princípio num sistema concentracionário, o caminho está aberto para que "o mal possa fazer então o trabalho sujo", na formulação agora de Z. Bauman ${ }^{22}$. Hannah Arendt diria que este caminho estava aberto precisamente porque

"no Terceiro Reich, o Mal perdera a qualidade pela qual a maior parte das pessoas o reconhecem - a qualidade da tentação. Muitos alemães e muitos nazistas, provavelmente a esmagadora maioria deles, deve ter sido tentada a não matar, a não roubar, a não deixar seus vizinhos partirem para destruição (pois eles sabiam que os judeus estavam sendo transportados para a destruição, é claro, embora muitos possam não ter sabido dos detalhes terríveis), e não se tornarem cúmplices de todos esses crimes tirando proveito deles, mas Deus sabe como eles tinha aprendido a resistir à tentação"23.

Estamos começando a ver que um tal aprendizado por assim dizer, resistir à tentação do bem — não teria sido possível sem a multiplicação exponencial dos pequenos e grandes laboratórios de experimentação do trabalho sujo

22. Ibidem, p. 235.

23. Eichmann em Jerusalém cit., p. 167. 
como efetivamente trabalho, sans phrase. $\mathrm{O}$ "trabalho do diabo", enfim, como o chamou certa vez Hitler, referindo-se à necessária "inteligência e dureza de nosso trabalho de limpeza"24. Resta a dúvida por onde começamos: no final das contas, porque o trabalho, com ou sem aspas, está sempre presente no coração da mais tenebrosa zona cinzenta da história?

3.

Uma coisa, porém, é o trabalho sujo repassado para agentes coagidos ou voluntários da "colaboração" - como os bons europeus de hoje reservam a sujeira do trabalho à mão-de-obra imigrada, assim como um sexto sentido histórico de classe deve ter orientado as primeiras terceirizações para os serviços de faxina e limpeza - , outra coisa quando esse mesmo "trabalho direto" é literalmente executado por uma autonomeada elite racial incumbida de purificar a espécie. Aliás "trabalho direto" como por vezes se exprime Hannah Arendt, a propósito, por exemplo, do "fato bem conhecido de que o trabalho direto dos centros de extermínio ficava usualmente nas mãos de comandos judeus"25. A seu ver, isso "era simplesmente horrível, não um problema moral”. Que, não tão obviamente assim, só começa a sê-lo quando tal "incumbência" retorna às mãos dos verdadeiros carrascos. Mais uma vez: fardo moral impiedoso porque se trata de um "trabalho" exercido no começo por, digamos, futuros ex-amadores.

24. Citado por Ian Kershaw Hitler, São Paulo: Cia das Letras, 2010, p. 555.

25. Eichmann em Jerusalém cit., p. 139.
O que antes cheirava a coisa imunda e manuseada por seres execráveis e massacráveis, é puxado agora do lodaçal para a altura sublime do ato heroico. Assim reabilitado, o trabalho sujo - que nos períodos por assim dizer normais da guerra social retorna ao seu aparente leito natural, o submundo do crime, da política e dos negócios - se revestirá de autêntica e inatingível grandeza histórica, graças à monstruosa proeza nazi, ao chamar para si a responsabilidade obscena de fazer desaparecer todo um povo da face da terra. Nosso sociólogo de há pouco, Everett C. Hughes, ao se referir com surpreendente precisão ao Holocausto como o mais colossal trabalho sujo da história, não tinha por certo a menor ideia do quanto esse anátema correspondia ao mais arraigado senso de missão - sempre entendida como uma atrocidade que de tão abominável chega a transfigurar o algoz - de um Heinrich Himmler, que em 4 de outubro de 1943, num discurso aos hierarcas SS reunidos na prefeitura de Posen, apresentou a Solução Final em andamento como "a mais gloriosa página de nossa história, uma página que jamais foi escrita e jamais poderá ser escrita" - justamente por tratar-se do mais colossal trabalho sujo da história, um segredo de polichinelo, porém sujo. Esta arenga blasfema, retomada dois dias depois no mesmo local, desta vez dirigindo-se aos maiorais do partido, é muito citada pela historiografia, em geral na forma de trechos escolhidos, de sorte que até agora não encontrei nada que corresponda ao que desconfio seja uma paráfrase, aliás, exata, de Zizek, que atribui a Himmler um improvável enunciado como o seguinte, atribuição duvidosa menos pelo teor de brutalidade do que pela estranhável consistência, digamos, conceitual: "é fácil fazer algo nobre por seu país, até mesmo dar a vida por ele; o verdadeiro heroísmo, todavia, 
consiste em fazer o trabalho sujo necessário: matar e torturar por seu país, assumir o fardo do mal"26. Seja como for, apócrifo ou não, nele se exprime a máxima de todas as guerras ditas sujas, ou assim chamadas pelos seus perpetradores, seu realismo comercial de segunda ("o preço a pagar”), o apelo à verdade das situações limite etc. Aliás, o comentário de Zizek, embora o repudie (era só o que faltava), não deixa de trair as afinidades vanguardistas dessa nobilitação do trabalho sujo: "esta é a atração secreta e sedutora do cinismo: viver na verdade e na bondade é entediante; o único desafio autêntico é do Mal, ou seja, o único espaço para feitos extraordinários se encontra em idiossincrasias transgressoras". Armação filosófica a menos, o que de fato se expressa nesse apelo redentor ao fardo do trabalho sujo é o supremo desprezo do miliciano de tropa de choque fascista pelo liberal de coração mole que lhe encomendou o serviço ${ }^{27}$.

Aqui o núcleo duro de todo o enigma. Do qual Hannah também se aproximou, sem atinar, porém, com o verdadeiro nome da coisa, se for permitida a impertinência. Depois de uma antologia de bolso das famigeradas tiradas de Himmler diante dos comandantes de Einsatzgruppen (Unidades Móveis de Assassinato, na sugestiva tradução de José Rubens Siqueira), sublinhando o teor ideológico praticamente nulo delas ao justificar o injustificável, também assinala que a única ideia que afetava a cabeça daquela gente, aliás muito bem coroada por uma grande variedade de diplomas universitários, que tinha se transformado num bando de assassinos em série, era a de "estar envolvi-

26. S.Zizek, Às portas da Revolução, São Paulo: Boitempo, 2005, p. 197.

27. Cf. Zizek, Bem-vindo ao deserto do real, São Paulo: Boitempo, 2003, p. 41. dos em algo histórico, grandioso, único, e que, portanto, deve ser difícil de aguentar". E assim sendo - "difícil de aguentar, pois não se tratava de sádicos ou delinquentes profissionais, pois sempre houve aliás um esforço sistemático para afastar todos aqueles que sentiam prazer físico no que faziam -, o problema do comando "era como superar não tanto a sua consciência, mas sim a piedade animal que afeta todo homem normal em presença do sofrimento físico". O artifício usado por Himmler vai direto ao ponto dos nossos clínicos do trabalho sujo. Na formulação precisa de Hannah Arendt: o truque era muito simples e provavelmente muito eficiente,

"consistia em inverter a direção desses instintos, fazendo com que apontassem para o próprio indivíduo. Assim, em vez de dizer 'que coisas horríveis eu fiz com as pessoas!', os assassinos poderiam dizer 'que coisas horríveis eu tive de ver na execução dos meus deveres, como essa tarefa pesa sobre meus ombros!'”28.

Novamente, o fardo do trabalho sujo em pessoa. Quando o peso se torna insuportável, os que fraquejam invocam com razão alguma repugnância meramente física, jamais qualquer aversão moral ou política - como não se cansará de observar Browning, investigando a paulatina profissionalização e dissociação caracterial dos massacradores do $101^{\circ}$ batalhão.

Voltando. Como se viu, trabalho sujo atende a uma demanda de terceiros (até mesmo na forma de uma ex-

28. Eichmann em Jerusalém cit., pp. 121-122. 
pectativa imaginária), que além do mais desfrutavam do privilégio de se fazer substituir - no fundo, o fascismo nada mais fez do que apresentar a conta à burguesia europeia, e no entanto, "o mais colossal trabalho sujo da história" foi encarado por aqueles que o realizaram não como uma estratégia subordinada a um objetivo ulterior, mas a bem dizer como um fim em si mesmo, como um empreendimento autosuficiente ${ }^{29}$. Nada a ver com as trevas impenetráveis do Mal Absoluto. O massacre não se organizou no vazio, continua Hilberg, acrescentando que tamanha hecatombe só pode acontecer porque ela tinha uma clara significação para os agentes que a perpetraram: tratava-se de uma peripécia percebida como uma realidade vivida de ponta a ponta por todos os seus protagonistas, da redação rotineira de um memorando ao abrir e fechar as portas de uma câmara de gás. Como sugerido desde o início, a chave do enigma está no trabalho, na organização do trabalho. Eis como Hilberg apresenta essa espantosa engrenagem "trabalhando". Por definição, não importa a hierarquia, empregados, civis ou militares, quando muito apenas tocam o serviço, caprichando apenas na embalagem das formalidades burocráticas. Deu-se então o verdadeiramente impensável: submetido à mais insana das provações "jamais uma máquina administrativa precisou suportar o peso de uma tarefa tão implacável" - o aparelho encarregado de encontrar uma solução final para a questão judaica na Europa não só resolveu o problema como se superou diante de obstáculos em princípio intransponíveis - neles incluídos os famigerados escrúpulos morais, afinal "nenhuma burocracia ocidental enfrentara um tal abismo entre os preceitos milenares da moral e a mais corriqueira ação administrativa". Simplesmente, todo um corpo administrativo canalizou rios de engenho e competência na direção exclusiva e obstinada da destruição dos judeus. "A cada fase do processo, seus agentes exibiram, na ausência de diretrizes, espantosos talentos de pioneiros, uma incrível coerência em suas atividades quando de fato não havia sequer um enquadramento jurisdicional apropriado, demonstrando uma compreensão fundamental da tarefa da qual estavam incumbidos, quando também não havia de fato nenhuma comunicação explícita (...) Visto retrospectivamente em conjunto, o projeto aparece como um mosaico de fragmentos mornos e banais. Ora, essa sucessão de atividades ordinárias, essas notas, relatórios, telegramas, arraigados no hábito, na rotina, na tradição, se transformaram em um processo de destruição em massa. Indivíduos perfeitamente ordinários iriam realizar um trabalho que não tinha nada de ordinário. Uma falange de funcionários, nas repartições do Estado e nas empresas privadas, operavam no sentido do objetivo final"30. A cada momento da escalada, dificuldades de toda ordem se intensificavam, e nem por isso o extermínio foi interrompido. À medida em que avança em sua reconstituição, o que realmente deixa nosso autor estupefato é a continuidade ininterrupta de todo o processo: no limiar da fase do morticínio direto, a torrente das medidas administrativas ainda mais se avolumava, "a marcha forçada sem precedentes de homens, mulheres e crianças para as câmaras de gás havia começado. Como se produziu tal façanha?". 
Está na hora de esmiuçar a resposta de Ch. Dejours: graças à capacidade de mobilizar o trabalho coordenado de uma enorme máquina de moer gente, graças ao esforço diligente de que se nutre todo o trabalho, a começar pelo sujo. A propósito: Zygmunt Bauman também leu Hilberg, entre tantos outros autores "não-intencionalistas", mas seria incorreto apoiar-se em sua reconstituição para sustentar a tese de que o Holocausto só se explica à luz da racionalidade burocrática, a ponto de afirmar que a própria ideia de Solução Final foi um produto da cultura burocrática. Isso dito, não resta dúvida de que o extermínio em massa em uma escala sem precedentes, "dependeu da disponibilidade de especializações bem desenvolvidas e firmemente arraigadas, e de hábitos de meticulosa e precisa divisão do trabalho, da manutenção de um fluxo contínuo de comando e informação ou de uma coordenação impessoal e bem sincronizada de ações autônomas embora complementares: daquelas habilidades, em suma, que melhor se desenvolvem e medram na atmosfera do escritório"31. Sem dúvida, a luz lançada pelo Holocausto sobre nosso conhecimento da racionalidade burocrática é estonteante, ainda mais se coarmos tal luz pelo filtro profético de Kafka e Weber, no entanto ainda mais esclarecedor é a verificação do salto "laborioso" que foi necessário dar para tornar efetivos comandos administrativos remotos. $\mathrm{O}$ que Raul Hilberg conseguiu mostrar - salvo engano de interpretação de nossos dois clínicos do trabalho - é que só podemos compreender o fenômeno abominável da destruição em massa dos judeus como um trabalho, trabalho genocida sem dúvida, mas de qualquer modo um trabalho,

31. Modernidade e Holocausto cit., p. 34. e como tal uma atividade que não se cumpre sem a contribuição autônoma de quem a executa, para além justamente dos automatismos burocráticos. Pelo menos é assim na leitura mais específica de Joseph Torrente: seu ponto nevrálgico é a compreensão do metafórico "trabalho do mal" como "trabalho atroz". Pois foi exatamente em torno da apologia de uma descomunal "coragem" transgressora exigida pelo mais sujo dos trabalhos atrozes que girou a sinistra oratória de Himmler naquele mês de outubro de 1943: só vocês sabem o que são 100 cadáveres alinhados um ao lado do outro, ou 500, ou até mesmo 1.000; e não obstante, aguentar firme - salvo raros casos de hesitação por compreensível fraqueza humana - como se espera de homens de bem, foi isso que forjou nossa têmpera inquebrantável e com ela se escreveu a página mais gloriosa de nossa história etc, etc ${ }^{32}$. É isso aí: só o trabalho de fato "liberta”. Está claro que num outro sentido muito mais terrível e verdadeiro que o mero escárnio da citação blasfema no frontispício de Auschwitz.

\section{4.}

Passemos então ao trabalho direto do mal, a maneira pela qual uma tarefa atroz é laboriosamente executada de modo a envolver seus agentes no halo de uma estranha virtude, sem a menor relação com a ação homicida que está sendo empreendida em uma escala inconcebível. Quer dizer, a lição extraída por nossos dois autores, Ch. Dejours e J. Torrente, das reflexões de Christopher Brow-

32. Citado por Hilberg cit., p. 1868. Estou estilizando, é claro, mas é isso mesmo: chacinar e enfileirar. 
ning sobre um massacre - o primeiro deles, o batismo de fogo, como se dizia no antigo regime da guerra - , quando ao amanhecer de um certo dia 13 de julho de 1942, o $101^{\circ}$ batalhão de reserva da polícia alemã entra na aldeia polonesa de Jozefow. De tarde, já haviam aprisionado 1.800 judeus: 300 são considerados aptos para o trabalho escravo, os demais, incluídos mulheres, crianças e velhos, são abatidos à queima roupa no bosque vizinho. Os quinhentos e poucos membros do batalhão não eram nem nazistas nem racistas fanáticos, eram alemães comuns provenientes da pequena burguesia de Hamburgo, muitos até de origem operária, homens maduros que haviam deixado atrás de si famílias bem estruturadas, como se diz. Antes do massacre porém, deu-se um fato extraordinário: tendo reunido aqueles "homens comuns", o comandante anunciou-lhes, ele mesmo, visivelmente abalado, a tarefa espantosamente "desagradável" que os aguardava, propondo-lhes ato contínuo uma saída inusitada: se alguém não se sentisse com forças suficientes para se desincumbir de tal missão estaria dispensado - por assim dizer no chão da fábrica, o script mesmo de Himmler, cinismo heroico a menos, acrescido da cláusula de escape, tanto mais vexatória por não implicar represálias. A imensa maioria, no entanto, preferiu obedecer, fazendo em um ano equatro meses mais de 83.000 vítimas, sempre abatidas pelo mesmo método do matadouro ad hoc - literalmente sujo, emporcalhado etc. Como diria o lamentável sobrevivente citado por Primo Levi, quem não enlouqueceu naquela primeira jornada de iniciação, logo se acostumou, tornando-se inclusive um exterminador minucioso e cumpridor. Como lembrado, esse um dos pontos de nossos dois autores, repassando a lição magistral de Browning: os poucos refratários que se abstiveram para não enlouquecer, contribuíram com essa fraqueza circunstancial para a banalização do crime que de modo algum estavam condenando, pelo contrário, esterilizavam o horror ao realçar assim a firmeza dos algozes que abatiam suas vítimas cara a cara.

Pelo menos na tradução francesa, volta e meia alguém menciona o sale boulot com o qual tinha de se defrontar, a começar pelo compassivo comandante Trapp. Naquela primeira hora, pouquíssimos se desviaram, e pelas razões tortas que se viu. Interessa muito mais as razões dos que aguentaram firme: todas elas convergem na transfiguração daquela "sujeira" toda em "trabalho", e trabalho de um coletivo no qual eficácia e qualidade são senhas de reconhecimento e pertencimento, como se diria no jargão contemporâneo. Atrocidade em nome do trabalho comum - assim como ninguém gostaria de se desmoralizar perante colegas, tampouco seria valorizado quem assassinasse por interesse pessoal perverso. O mais colossal trabalho sujo da história foi igualmente a mais espantosa operação de "lavagem", no caso a sublimação dos massacres sucessivos de inocentes graças à sua conformidade aos imperativos práticos de um trabalho bem-feito. Ocorre que este não existe sem um mínimo, quem diria, de astúcia - isso mesmo, aquele gênero de inteligência ardilosa que pode ser encontrada tanto em um herói homérico quanto na razão hegeliana agenciando o curso do mundo, como agora na experiência nazi no trabalho atroz que a tornou possível. Da seguinte maneira. O que de fato nos mostrou Christopher Browning? Que os policias enviados para limpeza na Polônia, não experimentando nenhuma satisfação especial, pelo contrário, naquela função macabra de executar durante horas e horas, um dia depois do outro, inocentes indefesos, aprenderam no ato os segredos do "trabalho de extermínio", concentran- 
do suas preocupações exclusivamente nas operações exigidas pelo trabalho, cujos "macetes" foram descobrindo ou inventando aos poucos. Como se tratava de matar no menor tempo o maior número possível, a execução logo se converteu num processo de apuração e aprimoramento das mais variadas técnicas e procedimentos: camadas sucessivas de vítimas deitando-se de bruços sobre os corpos ainda quentes da leva precedente exterminada; técnica da pontaria à queima roupa usando a ponta da baioneta como alça de mira, visando a nuca, nem muito baixo, pois aí o tiro pode não ser fatal, nem muito alto, pois nesse caso o crânio estilhaçado pela bala projetava sobre as botas, calças e túnica do matador, que deverá repetir a operação algumas dezenas de vezes, uma mistura lamacenta de sangue, miolos e fragmentos de osso, aí sim comprometendo a qualidade do serviço, além de por em risco o sistema de defesas morais e psicológicas, na ausência das quais o "sujeito" fatalmente sucumbiria, no caso, na vala comum das bestas-feras ou dos doentes mentais, como observou certa vez o chefe supremo das SS na Rússia Central ${ }^{33}$. À vista da dimensão estratégia dessa concentração de toda a atenção dos agentes da matança nos "desafios" (novamente o jargão contemporâneo se impõe com naturalidade) a execução propriamente dita, Ch. Dejours não hesita, pois a seu ver não há anacronismo nessa visão retrospectiva: como a mola nada secreta dessa "atividade" não é manifestamente uma perversão - jamais se viu uma ação tão

33. Segui passo a passo comentário de Ch. Dejours, op. cit., pp. 123-124. A referência ao olho clínico de Von dem Bach, encontra-se em Hilberg, op. cit., vol. III, p. 1862. Como o processo de destruição era um empreendimento organizado onde só podia haver lugar para outras tantas tarefas organizadas, seus "gestores" tinham plena consciência dos riscos que comportavam a pilhagem, a tortura, as orgias e demais barbaridades. Cf. Ibidem, p. 1863. deserotizada, muito menos o absurdo da violência como sublimação - nem a mera passagem ao ato de uma pulsão eliminacionista (para chegar ao extremo dos carrascos voluntários de um Daniel Goldhagen), tampouco efeito colateral de uma burocracia remota e despótica como no Castelo kafkiano ${ }^{34}$, ela deve ser procurada "na gestão a mais racional possível da relação entre tarefa e atividade, numa palavra, entre organização prescrita e organização real do trabalho". Penetramos assim no âmago da bizarra alquimia que transforma abominação em sublimação prossegue Dejours. O segredo dessa transfiguração não se encontra na violência exterminadora enquanto tal, nem como explosão furiosa, nem como fria crueldade premeditada, num caso, circunstância atenuante, no outro, agravante: o processo da violência enquanto injustiça de um sofrimento imposto só é canalizado com eficiência na direção sublimadora do bem se ela mesma, violência, for inserida no quadro de coerção própria do trabalho, que ele mesmo é sofrimento por enfrentar um real que resiste.

A certa altura do seu tratado sobre a violência, agora elevada à condição de novo Mal do século, Michel Wieviorka se depara com a hipótese de uma violência desprovida de sentido, nem déficit nem excesso, uma pura e simples ausência de sentido, hipótese ao seu ver equivocada que data do início dos anos 60 por ocasião do julgamento de Eichmann e a polêmica da tese de Hannah Arendt, cuja "intuição" (nas palavras da própria autora) da “bana-

34. É bem verdade, como escreveu Hilberg, que "quando o primeiro servidor público escreveu numa norma do funcionalismo a primeira definição de "nãoariano', nos primeiros dias de 1933, a sorte dos judeus estava selada”, citado por Z. Bauman, op. cit., p. 47. Todavia, não custa reparar: a passagem da norma ao fato escabroso induzido pela norma requer todo um processo de agenciamento e mobilização que só a diligência laboriosa dos operadores cumulativamente educados pelo trabalho atroz tornou possível. 
lidade do mal" Wieviorka por sua vez dilui numa pretensa cultura da obediência e da indiferença desdramatizadora: de fato, uma intuição insuportável, pois ela dissocia o ator de seus atos, abrindo um fosso entre concepção e execução, moral e juridicamente injustificável portanto. (Mas é no preenchimento deste intervalo capital que tudo se joga). É esse o caminho enviesado que o conduz até o livro de Ch. Browning, à barbárie dos homens comuns, ao problema da transformação de um grupo de alemães "normais" em matadores em série, metamorfose que passou longe de uma conversão automática, como já sabemos, pois precisou se debater e conviver com resistências de ordem moral e reações rudimentares de asco, sem prejuízo da rotinização subsequente da brutalidade sádica, entremeada pelas providências burocráticas de sempre - de todos os modos um cabal desmentido da hipótese da violência/mal absoluto se desencadeando no mais atordoante vazio de sentido. Seja como for, no esforço de reintroduzir algum sentido na conduta dos matadores - e por aí descartar a tese da banalidade do mal, tomada como variante das condutas de autoconservação por meio da fria submissão instrumental ao comando de uma autoridade absoluta - Wieviorka tangencia o argumento dos teóricos clínicos da nova centralidade do trabalho ao considerar o jogo das três lógicas que moldam a experiência dos ordinary men de Browning. A primeira seria a própria lógica burocrática e seus portadores submissos e impermeáveis aos sentidos de seus atos; com a qual se chocaria a lógica do excesso, a da crueldade sádica que perverteria a fria indiferença da primeira; comprimida entre elas, uma lógica moral que reluta diante da chacina direta, seja por sentimento de horror ou simples repugnância fí- sica $^{35}$. Mas para que o embotamento da sensibilidade seja total e se complete o processo de formação da atrocidade como prática do assassinato político em massa num ambiente de guerra total, como era o caso na frente oriental, era preciso que ocorresse mais que uma convergência de ocasião entre frieza burocrática na logística da limpeza e gozo sádico: justamente a Bildung parodicamente perversa mencionada acima (e cuja chave conhecemos: sim, aqui o trabalho também forma, mas para o Mal), nas palavras de Wieviorka, que no entanto não atina com sua lógica específica, a "experiência organizada da matança prática". Faltou apenas chamar esse savoir faire pelo nome. Mas para tanto seria preciso desviar a atenção do foco exclusivo no escândalo da violência como paradigma dos novos tempos - e sua correlata miopia para a mola secreta empilhando catástrofes no século passado. Reparando que a violência que de fato se alastra e impulsiona em proporções inéditas todo sofrimento social contemporâneo continua a brotar de uma zona central de conflito, do epicentro de uma terceira onda de intensificação "atroz" do trabalho ${ }^{36}$.

\section{5.}

Tocamos o fundo, o "real do trabalho", que se oferece ao sujeito que o confronta como a decalagem (além do galicismo obrigatório, estou citando) irresistível entre a or-

35. Cf. Michel Wieviorka, La violence, Paris: Hachette, 2006, pp. 250-252.

36. Sobre essa terceira onda de intensificação do trabalho no capitalismo, ver Sadi Dal Rosso, Mais trabalho! São Paulo: Boitempo, 2008. 
ganização prescrita do trabalho e a organização real do trabalho. Com efeito continua Ch. Dejours:

"Quaisquer que sejam as qualidades da organização do trabalho e da concepção, é impossível, nas situações ordinárias do trabalho, alcançar os objetivos da tarefa se respeitamos escrupulosamente as prescrições, ordenamentos e procedimentos (...) Se nos ativéssemos a uma execução estrita, nos depararíamos com a situação bem conhecida chamada 'greve do zelo’. O zelo é precisamente tudo o que os operadores acrescentam à organização prescrita para torná-la eficiente; tudo o que eles colocam em marcha individualmente e coletivamente e que não decorre da 'execução'. A gestão concreta da decalagem entre o prescrito e o real depende, de fato, da mobilização dos mecanismos afetivos e cognitivos da inteligência"37.

No limite, portanto, o trabalho é o trabalho vivo do zelo: definitivamente, insiste Dejours, "o trabalho não é inteiramente inteligível, formalizável e automatizável". Não se trata obviamente do trivial esmero de quem quer agradar o comprador de seu saber-fazer, mas de outra coisa - quem de fato trabalha sempre "faz outra coisa", por mais que pareça seguir escrupulosamente um script que ao cessar pode acarretar a pane de todo um sistema técnico produtivo. Não se trata de uma qualidade contingente do trabalhador, o zelo é não só central, mas decisivo,

37. Dejours, Souffrance en France cit., pp. 30-31. insiste Dejours. O assim chamado trabalho de execução é uma quimera. Nenhuma empresa, instituição, serviço, oficina etc funcionaria se os trabalhadores não acrescentassem à prescrição um sem-número de bricolagens, macetes, gambiarras, truques, sem que de resto lhes seja solicitado, longe disso: tais provas de inteligência e cooperação no trabalho coletivo são praticamente mobilizadas num estado de semiclandestinidade. Como resume $\mathrm{Ch}$. Dejours numa entrevista, "de certa maneira, trabalhar é trapacear"38.

Até chegarmos à centralidade do zelo no trabalho não são portanto poucos os mitos contemporâneos a serem postos à prova e demolidos, a começar pelo conto da erosão da própria centralidade do trabalho, a saber: que o trabalho passou dessa para melhor e o que sobrevive é um artigo escasso que atende pelo codinome "emprego", em vias de desaparição, por motivo de progresso tecno-científico, automatização, robotização etc, etc. Totalmente reprodutível e substituível por equivalentes maquínicos, o trabalho se resumiria quando muito à mera execução, de sorte que os únicos problemas residuais numa empresa residiram na concepção e na gestão. E por aí vamos, até o epílogo conhecido acerca da implosão da sociedade do trabalho: procura-se um substituto para o dito cujo em condições de fazer as vezes de mediador da subjetividade, da identidade e do sentido ${ }^{39}$. Não seria o caso agora de revirar pelo avesso todo esse quadro de clichês e meias-verdades, reexpondo, por exemplo, a simples título de

38. Entrevista dada a Jean-Michel Carré para o seu filme J'ai (très) mal au travail, (DVD, Éditions Montparnasse, 2009), comentado por Patrick Coupechoux, La deprime des opprimés cit., p. 245.

39. Souffrance en France cit., pp. 47-48. 
contraprova acachapante, a verdadeira carnificina em que se converteu esse famigerado mundo do trabalho, presumidamente em extinção, devastado pela denegação extorquida do sofrimento, do gesto amputado, da ação impedida, pelas armadilhas do medo instituído, pela culpabilização e vergonha política de tornar público tais estragos etc. Todavia, a evidente exaustão dessa lenga-lenga sobre o fim do trabalho e seus derivados não significa em absoluto que continuamos na mesma. Pelo contrário, há mais de 30 anos testemunhamos a imposição traumática de uma grande mutação. Como lembrado no início, o Neoliberalismo não é uma simples restauração que teria fechado o breve parêntese do Estado Social, nem mesmo consequência de uma expansão imanente da lógica capitalista de valorização e anexação de novos territórios para acumulação ${ }^{\mathbf{4 0}}$. Reviravolta responsável inclusive por toda essa recentralização negativa do trabalho na origem da atual explosão de um novo sofrimento nas empresas e nas sociedades - e da qual, não por acaso, a análise psicodinâmica das situações do trabalho é contemporânea, como também sugerido de início.

Se assim é, seria o caso quem sabe de "datar" a redefinição do trabalho pelo prisma do zelo - sem a qual, de resto, seria impossível redescobrir todo o horror frio do "zelo" com que Eichmann se desincumbia do trabalho prescrito da destruição, ou melhor, subentendido por um cipoal de microcomandos - interpretando-a como uma resposta ao engodo de massa presente no âmago daquela grande mutação que teria vindo justamente, entre tantas outras "liberações" anunciadas para uma sociedade salarial, então em

40. Para uma rápida desmontagem dessa narrativa compensatória, Pierre Dardot e Christian Laval, "Néoliberalisme et subjectivation capitaliste", Cités n. 41, Paris: PUF, 2010. pé de guerra ao longo de toda a década de 70, para libertar o "trabalho efetivo" do "trabalho prescrito", sob o jugo do qual penavam os servidores da loucura racional taylorista-fordista ${ }^{41}$ : afinal, a agenda libertária de Maio de 68 não fora declinada também segundo o léxico antiprodutivista e antiautoritário da autonomia, impossível de predeterminar, programar e prescrever etc? Pois no calor da luta de classes (visível na desimplicação no trabalho, na resistência passiva dos assalariados, nas ocupações, sabotagens de toda ordem, sequestro degerentes, etc), a reorganização dita "flexível" do trabalho recapturou toda essa energia em movimento, reinventando-se algo como uma "mobilização por decreto". Ou, como prefere Yves Clot, procurando entender os paradoxos atuais de "uma mobilização subjetiva a um só tempo exigida e recusada como foi o gesto no período taylorista", no fundo, paradoxo da autonomia, pois as mudanças em direção de uma maior autonomia não equivalem a um progresso, pois a real "desprescrição operatória" encaminhada por um lado, é anulada, pelo outro, pela pressão temporal exercida pela tirania do curto prazo. Sendo no limite o controle externo substituído pelo autocontrole, entramos no domínio de uma violenta "autoprescrição", cujos efeitos sobre o sujeito significam devastação física e mental ${ }^{42}$.

41. Ainda vale a pena ler, e como, o livro de Bernard Doray Le taylorisme, une folie rationnelle? Paris: Dunod, 1981.

42. Cf. Yves Clot, "Le sujet au travail", in Jacques Kergoat, Josiane Boulet et alii, Le monde du travail, Paris: La Découverte, 1998. Para um resumo do itinerário de reconversão da embriaguez de 68 na ressaca gestionária que deu uma segunda vida sistêmica ao sale boulot, ver Patrick Coupechoux (op. cit., pp. 215-221). A suma a respeito dessa transfiguração ainda é o pavê de Luc Boltanski e Ève Chiapello, Le nouvel esprit du capitalisme, Paris: Gallimard, 1999. E o capítulo pioneiro a respeito da matriz meia oito do novo discurso da autenticidade managerial, Jean-Pierre Le Goff, Le mythe de l'entreprise, Paris: La Découverte, 1992. 
Tudo se passa, portanto, como se o zelo, sem o qual o trabalho não se realiza, tivesse sido redescoberto, e reconduzido ao seu lugar de origem de desbravador do caminho que conduz ao "real", através de sua paródia gestionária: sendo por definição algo imprevisível, reapresentou-se como uma conduta governável pelo incitamento bipolar tanto à transgressão das rotinas administrativas burocratizantes e apassivadoras, quanto à autovigilância implicável movida pelo medo de ser mal avaliado. Que é apenas o primeiro capítulo, a porta de entrada da exploração pelo sofrimento, ou melhor, do sofrimento, do qual nos livramos erguendo barreiras de proteção que uma vez convertidas em defesas de adaptação já se tornaram defesas exploradas. Os mecanismos de defesa gerados pelo medo do sofrimento (ou o sofrimento do medo) são assim o cavalo de Tróia da exploração do trabalho - afinal se trata de "um sistema funcional que torna possível a submissão às tarefas através do 'equilíbrio' dos sujeitos, mesmo ao preço de estabilidades mórbidas"43. Para surpresa das certezas clássicas acerca da motivação no trabalho, assentadas na convicção que só a livre vontade dos trabalhadores mobiliza inteligência e engenho, o novo management revelou que o zelo passou a responder à pressão do medo, que ao invés de paralisar a inteligência, pode desovar "tesouros de inventividade para melhorar a produção e constranger os vizinhos”. Mas ao contrário da elasticidade indefinida da mobilização da inteligência pelo reconhecimento do trabalho bem feito, a escalada da gestão pela ameaça tem limites, para além dos quais a

43. Nas palavras de Yves Clot, Le travail suns l'homme? (Paris: La Découverte, 1995, p. 244), comentando a primeira figura da psicopatologia do trabalho segundo Ch. Dejours. inteligência congela e a moral do coletivo quebra, mesmo nas situações extremas, como a guerra ${ }^{44}$.

Duas palavras mais. O "real" aqui é justamente o que oferece resistência à maîtrise, o que resiste ao procedimento prescrito e que portanto surpreende. Onde há resistência, há malogro e persistência, por isso o trabalho é uma experiência igualmente afetiva. Há portanto sofrimento no trabalho, porém sofrimento que orienta e inteligência. E se há frustração, o prazer está sempre no horizonte. Noutras palavras, Ch. Dejours encaixa o trabalho numa estrutura triádica, entre a ação e o sofrimento. Só para lembrar - na contramão da dissociação fatal ação instrumental/interação social — que trabalhar não significa apenas entregar-se a uma atividade, e que não se pode agir sem que algum trabalho seja produzido. Pois é justamente essa imbricação entre ação e trabalho que explica o consentimento e a colaboração de massa no exercício do mal. Dito de outro modo: ação e trabalho não são conceitualmente solúveis um no outro, mas eventualmente, a depender da situação, podem sofrer um processo de redução mútua - sempre segundo Ch. Dejours. Foi o que se viu na situação extrema descrita por Christopher Browning. Os sujeitos daquela ação - seja dito sem humor negro, além do mais deslocado - só puderam aguentar firme, afrouxando a relação consciente com o sentido de uma ação de tal modo pavorosa, deixando-se ocupar inteiramente pelas exigências específicas de um "trabalho" encarado como atividade meramente instrumental. E como também se viu: a redução da ação à atividade não resulta apenas do esgotamento mental, de embrutecimento físi-

44. Ainda Ch. Dejours, op. cit. pp. 68-69. 
co, mas igualmente de uma estratégia defensiva em face do sofrimento causado pela própria natureza da ação em andamento - reduz-se assim voluntariamente o campo da consciência à esfera restrita da atividade. $O$ espectro dessas atividades de trabalho em situação de choque é amplo - e Ch. Dejours pesquisou uma gama reveladora delas, dos matadouros às forças armadas, passando por necrotérios e institutos médico legais ${ }^{45}$. Em resumo, o zelo reúne aquelas duas dimensões da inteligência no trabalho: enfrentar o imprevisto, o inédito, nem conhecido nem rotinizado, mobiliza a dimensão cognitiva dessa faculdade; já as características afetivas estão implicadas na inteligência que arrisca contornar a norma porém sem alarde, e discretamente, quebrar a disciplina ${ }^{\mathbf{4 6}}$.

6.

Dessa redescoberta do zelo como mola secreta do trabalho vivo se depreende que o sale boulot requer um zelo redobrado. De volta ao auge nazista do trabalho sujo, só o zelo explica a eficiência daquela máquina exterminadora. Os quadros do sistema não eram simples peças de uma engrenagem maléfica que os ultrapassava. A obstinação com que consumaram a Solução Final não se devia apenas à óbvia disciplina, mas à sua superação pelo zelo: "se o sistema nazi de produção e administração funcionou, é porque, em massa, os trabalhadores e o povo inteiro con-

45. Cf. Ch. Dejours, Le corps entre biologie et psychanalyse (Paris : Payot, 1987), citado e comentado no capítulo de Yves Clot sobre a psicopatologia do trabalho, em Le travail sans l'homme? cit.

46. Cf. Ch. Dejours, Souffrance em France cit., p. 67. tribuíram com sua inteligência e seu engenho"47. Numa palavra, colaboraram zelosamente. Resta é claro o enigma Eichmann, a um tempo obtuso, ou melhor, uma enciclopédia de ideias feitas sobre Deus e sua época, e um campeão no zelo do trabalho do mal. De sorte que a banalidade desse último pouco tem a ver - não custa insistir - com uma outra falsa evidência assustadora, ela mesmo devedora de uma imagem burocrática da burocracia, a constatação de que

"o mais terrível dos males de que se tinha memória (...) não foi obra de uma turba ruidosa e descontrolada, mas de homens uniformizados, obedientes e disciplinados, cumpridores das normas e meticulosos no espírito e na letra de suas instruções" ${ }^{\text {"48 }}$.

Veja-se como resvalamos no estereótipo, por exemplo, na leitura do seguinte panorama descortinado por Hilberg, se preguiçosamente orientada pelo presumido tipo ideal da burocracia prussiana: ao contrário dos países aliados ou satélites, o pessoal da burocracia alemã

"não se deixava desencorajar pelos problemas, não recorria jamais ao faz-de-conta, como os italianos, nem a medidas simbólicas, como os húngaros, nem aos perpétuos diversionismos dos búlgaros. Os administradores alemães davam o melhor de si. Diferentemente de seus

47. Ibidem, p. 67.

48. Z. Bauman op. cit., p. 178. 
colaboradores estrangeiros, os alemães não se contentavam jamais com o mínimo: eles faziam sempre o máximo".

O trecho é citado por Joseph Torrente, que relembra a propósito que o trabalho jamais se cumpre sem o aporte autônomo da parte executante, a parte oculta do iceberg da produção, em suma, que a destruição dos judeus europeus foi

"o produto de uma atividade gigantesca da parte de trabalhadores zelosos, geralmente empregados em tempo parcial, sobrecarregados de demandas por satisfazer nos diferentes fronts da guerra e que no entanto encontraram o tempo e a astúcia necessários para levar esse processo até o fim"49.

Entre a letra e o espírito portanto, devemos agora acrescentar o zelo pessoal se quisermos entender de vez "como se elabora a capacidade coletiva de tornar o ato de matar um trabalho", na fórmula conclusiva de J. Torrente, depois de resumir a impressionante demonstração de Hilberg nos seguintes termos, justamente nos termos do trabalho fornecido pelo zelo, de modo a rever a Shoah não como uma catástrofe ética irrepresentável, mas como o fruto do trabalho dos homens:

"De sua visão de conjunto da Shoah decorre uma ideia mais precisa do processo assassino:

49. J. Torrence, “Travail et banalité du mal” cit., pp. 136-137. iniciativa, zelo, tenacidade, firmeza nas tomadas de decisão, obstinação no cumprimento de uma tarefa homicida. O encarniçamento, o esprit de suite dos alemães que participaram de todo o processo mostra muito mais do que um comportamento dócil. Foi preciso refletir, se motivar, remover os obstáculos administrativos, econômicos, militares, não se deixar extraviar em meios a dossiês numerosos e enredados, enfim, mobilizar-se totalmente, intelectualmente e afetivamente, dar prova de uma grande e constante implicação"50

“Mobilização", “implicação" etc: novamente o léxico das novas estratégias de organização e subordinação do trabalho não figuram aí por acaso, nem destoam, caso seu emprego decorresse de a nacronismo deliberado, para fins de desmoralização recíproca dos períodos históricos justapostos, além do mais reunidos, passado fascista e presente neoliberal, pela ideia de mobilização total, ideia de estado-maior que Ernst Jünger, no entreguerras, elevou à condição de conceito histórico-filosófico, como se há de recordar e noutra ocasião trataremos de reexaminar - pois afinal, no Terceiro Reich o que houve foi também uma mobilização total do trabalho sujo. Que não se move sem zelo, seja o trabalho do mal direto ou executado à distância. Ainda Hilberg, desta vez citado por Zigmunt Bauman, a propósito do trabalho sujo à distância, distanciamento propiciado pela divisão burocrática das especializações:

50. Ibidem, pp. 161, 139-140. 
"deve-se ter em mente que a maioria dos participantes do genocídio não atirou em crianças nem despejou gás em câmaras de gás (...) A maioria dos burocratas compôs memorandos, redigiu planos, falou ao telefone e participou de conferências. Podiam destruir todo um povo sentados em suas escrivaninhas"51.

Proeza infernal que jamais se consumaria sem o zelo no trabalho de uma legião de colaboradores, como estamos vendo a todo momento.

O zelo redobrado exigido pelo trabalho sujo carece da mesma maneira de um corpo de funcionários e operadores diretos dotado de um "espírito de iniciativa" servido igualmente em dose dupla: afinal, a decalagem entre o prescrito e o efetivamente realizado, nesse caso, era simplesmente monstruosa. Um exército de assalariados, mas na sua maioria funcionários públicos, confrontados com uma prescrição simplesmente horrenda. Isso por um lado. De outro, revestem com a rotina anódina de decretos e leis um processo sem precedentes, a bagatela de um massacre em escala continental. Do que resulta, continua Torrente, sempre na esteira de Hilberg, o fenômeno surpreendente de todo um corpo administrativo formado à sombra da rotina meticulosa que se sabe, impulsionado por um esforço inaudito de zelo, livrar-se aos poucos - até a mais completa autonomia - de toda uma carapaça legal, jurídica e administrativa. Pensando bem, o zelo nunca é de fato excessivo, embora sempre o seja. No dicionário de Flaubert, se o zelo por acaso comparecesse, com certeza esta-

51. Modernidade e Holocausto cit., p. 44. ria acompanhado de um inevitável "sempre excessivo" - ou ainda por outra, ele o é na sua justa medida, sendo o que de fato é, como se viu: uma permanente derrogação em ato do prescrito, um rodeio constante para melhor trapacear a norma. Talvez caiba ao zelo o que já se disse da polícia: um golpe de estado permanente ${ }^{52}$. Aliás, a polícia é o lugar natural do trabalho sujo, a esfera por excelência em que o trabalho sujo é a regra, uma greve do zelo na polícia seria o colapso total de todos os serviços. De algum modo, diante das portas do inferno, zelo e estado de exceção permanente se reforçavam mutuamente. A "sujeira" paradoxalmente produzida pela paranoia eugenista do Terceiro Reich algo tem a ver com o avesso obsceno da exceção soberana - de um ponto de vista constitucional, uma estado de sítio que durou 12 anos, ou uma guerra civil legal autorizando a eliminação de categorias inteiras de cidadãos. Vistas então as coisas por esse ângulo, não surpreende que J. Torrente encontre nos "funcionários zelosos do genocídio" descritos por Hilberg a pertinácia de um esprit de suite todo ele voltado não só para uma incessante transgressão da lei - afinal o Guardião da Constituição era o próprio Führer - mas sobretudo para um sistemático e inventivo détournement das regras administrativas, tanto mais revelador do zelo transgressor requerido para a realização concreta do massacre, quanto se sabe que o paradigma de governo pela exceção é a proliferação de regulamentos e decretos em detrimento da lei em sua acepção moderna - o que se pode compreender, aliás, sendo a vontade do Führer a única fonte da lei e suas ordens a única lei válida, de sorte que a lei pode entravar a

52. Foucault, sobre a instituição da polícia nos primórdios da modernidade, Sécurité, territoire, population, Paris: Gallimard/Seuil, 2004, p. 347. 
vontade se ela é muito escrupulosamente respeitada. Justamente uma tal proliferação (que não à toa lembra muito o governo colonial por decreto, na caracterização do Imperialismo oitocentista que Hannah Arendt reconstitui como o elo mais forte na genealogia do fascismo) é um instrumento maior do golpe de Estado diário que define a polícia moderna segundo Foucault, uma instituição (do trabalho sujo) que opera muito mais com regulamentos do que com leis: estamos assim "num mundo do regulamento indefinido, do regulamento permanente, do regulamento perpetuamente renovado, do regulamento cada vez mais detalhado"53. Para além da evocação imediata de Kafka (de fato, a espera perpétua nunca se deu diante da Lei, mas diante do Regulamento, de tal modo, este último, desjuridicizado, informalizado, a ponto de seu caráter ad hoc se afunilar numa única exceção individual), esse quadro recobre imediatamente a experiência devastadora da ausência de normas que regia a vida nos campos de concentração, como observa muito bem Jeanne Marie Gagnebin ao apresentar O que resta de Auschwitz de Giorgio Agamben:

"A administração nazista estabelece uma 'ordem' tão rígida quanto aleatória, os presos são entregues a um arbítrio implacável (...) Essa ausência de normas [podia acontecer que uma determinada regra fosse aplicada para logo ser descumprida no momento seguinte, revogada por outra cuja existência se ignorava, porque acabava de ser editada, P.A.] explica também

53. Ibidem, , p. 348. porque os novos detentos foram geralmente derrubados já nos primeiros dias de sua estada no campo. Perdiam tempo e energia em tentar compreender aquilo que lhes acontecia, em entender o sistema que regia o campo"54.

Claro que havia método naquela volubilidade despótica, uma autotransgressão por capricho no zelo do trabalho do mal. Ainda Hilberg: "em última análise, as leis ou os decretos não eram considerados como uma fonte última de poder, mas simplesmente como expressão de uma vontade" 55 . O zelo dos agentes do trabalho sujo consistia portanto no supremo engenho de decifrar a vontade do comando na ordem, em geral vagamente de caso pensado. De novo Hilberg: "os velhos princípios dos procedimentos legais, com todas suas exigências, eram percebidos como obstáculos. Sentindo a necessidade de agir sem restrições criaram um clima que lhes permitisse afastar progressivamente o modus operandi do formalismo escrito". Por excesso de zelo (agora nos entendemos) algumas instruções podiam simplesmente não ser levadas em conta. E prossegue J. Torrente, que acabei de citar parcialmente:

"certas instruções podiam ser simplesmente desconsideradas. O burocrata alemão se permitia transmitir um certo número de ordens sem que houvesse nem lei nem decreto de aplicação. Com frequência, no que concernia ordens de grande importância para a realização

54. O que resta de Auschwitz cit., pp.12-13.

55. Citado por J. Torrente, op. cit., p. 138. 
do processo, as instruções verbais substituíam as diretrizes escritas. E nem por isso deixavam de ser compreendias e seguidas”.

Por fim, mais uma vez Hilberg:

"Assim, existia de fato uma atrofia das leis e uma multiplicação correspondente de medidas, com respeito às quais as fontes de autoridade adotavam uma atitude cada vez mais evanescente. Abriam-se as válvulas para que a decisão passasse (...) Um burocrata médio, tanto quando seu superior hierárquico, situado no mais alto escalão, tomava consciência desses fluxos e das possibilidades, tanto nos detalhes quanto no contexto mais geral, ele sabia reconhecer o que estava maduro num dado período. E, frequentemente, senão sempre, era ele que desencadeava a ação"56.

Essa a engrenagem de exceção permanente polida pelo zelo no trabalho coletivo dos massacres administrativos ${ }^{57}$.

56. Ibidem, p.139.

57. Sobre a avalanche de decretos de emergência, a indistinção decorrente entre lei e regulação administrativa, a desformalização do direito e o alucinado decisionismo que caracteriza o sistema nazi de soberanias avulsas e independentes, o conjunto desse ordenamento errático e, no entanto, incrivelmente bem ajustado à exploração econômica de uma Europa convertida numa monstruosa sweat shop. - ver o capítulo de William Scheuerman sobre a interpretação do Terceiro Reich no Behemoth de Franz Neumann, Between the Norm and the Exception (Cambridge: The MIT Press, 1994). Além é claro, das páginas clássicas do original, lido, porém, na tradução francesa, (Paris: Payot, 1987, pp. 413-428).
7.

Como lembrado, já no emprego corriqueiro da expressão "trabalho sujo" encontra-se subentendida a encomenda de um terceiro cuja posição envolve uma supremacia qualquer, que autoriza e sanciona, para todos os efeitos "lavando a sujeira". (Noutra escala, como acabamos de sugerir, normalizando a exceção. Ou ainda, banalizando o mal, por exemplo, quando um empregado das ferrovias tarifava para as SS um deportado por quilômetro rodado, cobrando escrupulosamente apenas a ida). No Terceiro Reich não havia a menor dúvida sobre a identidade do Terceiro para o qual se fazia o trabalho sujo. Ora literalmente, ora metaforicamente, trabalhavam todos para o Führer. Quando deu meia-noite no século passado, a expressão "trabalhar para Hitler" condensava efetivamente em uma só fórmula encantatória todo o complexo andamento do "mais colossal trabalho sujo da história", para voltar mais uma vez ao achado do Professor Hughes. Até onde sei, foi Ian Kershaw quem atinou com o verdadeiro abre-te-sésamo cifrado nesta palavra mágica ao dar com ela num discurso rotineiro de um funcionário de segundo escalão - um secretário de Estado no Ministério da Agricultura prussiano - , mal completado um ano de regime: não havia dúvida, nela se encontrava a chave para a compreensão do funcionamento do Terceiro Rei$\mathrm{ch}^{58}$. A fala do secretário, arengando seus homólogos dos demais Länder, vale a citação: depois de lembrar que o Führer não podia cuidar de tudo, quer dizer "tudo o que pretende realizar mais cedo ou mais tarde", conclui que,

58. Cf. Ian Kershaw, Hitler cit. pp. 352-353 sq. 
até agora, "cada um trabalhou melhor na nova Alemanha se, por assim dizer, trabalhou para o Führer", para logo adiante trocar em miúdo esse "por assim dizer": a saber, que não se deve "esperar por comandos e ordens", mas ao contrário:

"é dever de cada um tentar, no espírito do Führer, trabalhar para ele. Quem cometer erros vai notar logo isso. Mas aquele que trabalha corretamente para o Führer, conforme suas diretrizes e voltados para seus objetivos, terá no futuro, como anteriormente, a melhor recompensa de um dia alcançar subitamente a confirmação legal de seu trabalho".

Impossível um recado mais espontaneamente inequívoco. Está tudo ali, do acobertamento legalista do inominável à confiança de que as iniciativas contariam com o respaldo superior, em suma, da exceção como paradigma de governo ao mais selvagem carreirismo, era tudo uma questão de prever, mas sobretudo antecipar a vontade do Führer, cuja decifração levava inexoravelmente ao conflito endêmico entre todos os escalões do zelo que irrigavam as províncias soberanas e beligerantes do Partido, da Administração estatal, das Forças Armadas, e dos Monopólios privados. Para os perpetradores oficiais "trabalhar para o Führer" tinha um significado literalmente óbvio - aliás não tão óbvio assim, até atinarmos com o real significado histórico do "trabalho" àquela altura. Mas também “trabalhavam para o Führer”, num sentido muito concreto para ser apenas figurado e indireto, não só os cidadãos comuns em pleno exercício do sale boulot ao denunciar seus vizinhos à Gestapo, seja por ressentimen- to pessoal ou para tirar vantagem com a calúnia política, mas igualmente, prossegue Kershaw, "os empresários felizes para explorar a legislação antissemita para se livrar dos concorrentes", sem falar na legião de "formas diárias de pequena cooperação", todos irmanados no zelo graças ao qual "tomavam-se iniciativas, criavam-se pressões, instigavam-se leis, tudo de um modo alinhado com o que se supunha serem os objetivos de Hitler e sem que o ditador tivesse necessariamente que os ditar"59.

Por temperamento pessoal Hitler não agia jamais como um burocrata - observa Kershaw, diante de um fenômeno a seu ver extraordinário: "um estado altamente moderno e avançado, sem órgão central de coordenação e com um chefe de governo em larga medida desconectado da máquina governamental", como exigia o distanciamento mítico necessário ao exercício de seu papel de Führer. No fundo, continuava um diletante, mas agora redefinido na acepção de Weber, na boa lembrança de Bauman : “O 'líder político' encontra-se na posição do 'diletante' que se opõe ao 'especialista', enfrentando funcionários experimentados que se acham dentro da administração do governo"60. Porém com uma inflexão que Weber não previra: ao invés da resistência inercial de uma burocracia racional frente ao diletantismo de um paranoico, o "esforço diligente" de uma multidão descentralizada "trabalhando para Hitler" e demonstrando grau surpreendente de liberdade de manobra e de variações administrativas locais: assim, e quem relembra agora é Robert Paxton, nos Estados Bálticos ocupados e na Polônia Oriental, já em

59. Ibidem, p. 354.

60. Modernidade e Holocausto cit., pg.35. 
agosto-setembro de 1941, alguns administradores haviam cruzado por conta própria a linha que separava matar por razões de "segurança" da matança maciça de populações inteiras, sem dúvida ações de iniciativa local que entretanto confiavam na aprovação de Berlim ${ }^{61}$. Um sistema de livre iniciativa verdadeiramente elástico até o limite da exceção permanente. Assim, voltando à síntese de Paxton, "na selva que era a administração nazista dos territórios orientais ocupados", o Führer para o qual se trabalhava - como observado, situado acima e além do Estado - era visto como uma instância totêmica suprema voltada para a recompensa das iniciativas precursoras, por assim dizer radicais, na sua liberdade de inventar, uma vez que no fragmentado sistema nazista de administração "não se exigia prestação de contas" dos excessos no zelo, como já sabemos até demais. Paxton porém parece restringir esse regime selvagem de livre iniciativa premiada aos territórios ocupados enquanto espacialização plena do vazio jurídico da exceção consumada em seu grau máximo. Não por acaso campos e massacres à queima-roupa se multiplicaram naquele outro lado da linha. Por assim dizer Paxton adota literalmente, ou melhor, espacialmente, a tese clássica de Ernst Fraenkel (exposta pela primeira vez ainda nos anos 30) acerca do caráter dual do regime jurídico no Terceiro Reich: prevalência incontrastável de um "Estado prerrogativa”, centrado na exceção soberana, sobre o Estado baseado em normas, ainda exigido pelas relações capitalistas liberais remanescentes no Reich - como vimos, no capítulo já referido de Scheuerman, o panorama reconstituído por Franz Neuman poucos anos depois vai

61. Robert Paxton, A anatomia do fascismo cit., p. 264. na direção contrária: a intensificação monopolista do capitalismo contemporâneo exigia cada vez mais comandos administrativos de exceção, dispensando de vez o estorvo liberal do rule of law. Paxton ainda justapõe espacialmente essa coexistência hierárquica dos dois regimes - não por acaso à imagem e semelhança da relação metrópole/ colônia à época da expansão ultramarina da burguesia oitocentista, só que agora concentrada na Europa ocupada e anexada.

"Nas áreas capturadas da Polônia e da União Soviética, organizações paralelas como a agência do partido que confiscava terras para redistribuí-las entre os camponeses alemães tinham mais liberdade que no Reich. A SS montou seu próprio império militar econômico nos locais onde o estado normativo praticamente não atuava. Nessa terra de ninguém, tanto a normalidade burocrática quanto os princípios morais eram fáceis de serem deixadas de lado (...) Naquele não-Estado sem nome, nazistas fanáticos tinham total liberdade para realizar suas fantasias mais loucas de purificação racial, sem a interferência de um Estado normativo distante" 62 .

De qualquer modo é inegável que foi justamente naquelas terras de ninguém de um não-Estado sem nome que os primeiros massacradores face-a-face foram treinados na escola do trabalho sujo que o zelo da iniciativa pes-

62. Ibidem, pp. 268-269. 
soal tornava maleável, inclusive para fins de equilíbrio psíquico suportável, como se viu.

Trabalhar para o Führer, portanto, era tudo menos uma exortação banal. O mais espantoso naquela configuração era que ela podia inclusive se dar ao luxo de mimetizar o funcionamento da Razão Prática kantiana - justamente sobre um imperativo moral, cujo núcleo intratável de asséptica rigidez sempre levantou a suspeição de pureza por omissão, apanágio de uma bela alma imaculada, mas antes por falta de mãos para eventualmente sujá-las no jogo bruto do mundo, recaía agora a atribuição espúria de fundamentar o zelo no trabalho sujo que valia como um dever-ser ajustado a um período de crime legalizado pelo Estado. Como a certa altura de seu julgamento Eichmann escandalizara o tribunal alegando ter agido sempre segundo a definição kantiana do dever, Hannah Arendt lembrou que tal blasfêmia não era escárnio cínico porém decorrência lógica do obsceno "imperativo categórico do Terceiro Reich", formulado alguns anos antes pelo governador geral da Polônia Ocupada, Hans Frank, nos seguintes termos: "aja de tal modo que o Führer, se souber de sua atitude, a aprove"63. Sem tirar nem por, uma ética do trabalho sujo em sintonia com o espírito do capitalismo, seja ela calvinista ou nazista. Eichmann podia ser banal, mas não era estúpido ao ajustar para si o que ele mesmo batizou de versão da moral kantiana do dever para uso doméstico do homem comum, mas homem comum trabalhando para o Führer: "nesse uso doméstico", prossegue Hannah Arendt, "tudo o que resta do espírito de Kant é a exigência de que o homem faça mais do que obedecer a lei, que vá além do mero chamado da obediência e identifique sua própria vontade com o princípio que está por trás da fonte de onde brotou a lei. Na filosofia de Kant, essa fonte é a razão prática; no uso doméstico que Eichmann faz dela, seria a vontade do Führer"64.

De volta ao coração do zelo no trabalho de um funcionário do mal. Ficaremos aquém da horripilante enormidade do caso se observarmos que o seu "minucioso empenho na execução da Solução Final" não era nada mais do que se devia esperar de um perfeito burocrata. A convicção de que "é preciso ir além do chamado do dever" só ocorreria a quem estivesse trabalhando para o Führer, na acepção escabrosa que se viu quando a ênfase recai sobre o trabalho.

Como ficamos? Com certeza na obrigação de passarmos à janela geminada desta "visão" francesa da sujeira no trabalho, que nossos dois autores não tiveram tempo de abrir. Revendo pelo prisma nazi do genocídio como trabalho o capítulo stalinista do extermínio pelo trabalho, não sem surpresa verificaríamos que a Era dos Extremos de Hobsbawm foi antes de tudo o Século do Trabalho Sujo. Restaria saber o que veio depois, se é verdade que o sale boulot do século XXI começou com a grande transformação neoliberal.

64. Ibidem, p. 154. 


\section{BIBLIOGRAFIA}

AGAMBEN, Giorgio. (2008), o que resta de Auschwitz. São Paulo: Boitempo.

ALY, Götz. (2007), Hitler's Beneficiaries: How the Nazi Bought the German People. Londres: Verso.

ARENDT, Hannah.(2004), Origens do totalitarismo. São Paulo: Cia das Letras. (1999), Eichmann em Jerusalém .São Paulo:

Cia das Letras.

BAUMAN, Zygmunt. (1998) Modernidade e Holocausto: Rio de Janeiro: Zahar.

BOLTANSKI Luc e CHIAPELLO Ève. (1999) Le nouvel esprit du capitalisme. Paris: Gallimard.

BROWNING, Christopher. (2007), Des hommes ordinaires: le $101^{e}$ batallion de réserve de la police allemande et la Solution Finale en Pologne. Paris: Taillandier.

CLOT, Yves. (1998), "Le sujet au travail", in KERGOAT, Jacques ; BOULET, Josiane et alii, Le monde du travail. Paris: La Découverte.

(1995), Le travail suns l'homme? Paris: La Découverte.

CONNELLY, John. (2009),“It never occurred to them”,
London Review of Books, de 27/08/2009.

COUPECHOUX, Patrick. (2009), La déprime des opprimés : enquête sur la souffrance psychique en France. Paris: Seuil.

DAL ROSSO, Sadi. (2008) Mais trabalho! São Paulo: Boitempo, 2008.

DARDOT Pierre e LAVAL Christian. (2010a), La nouvelle raison du monde: essai sur la societé néoliberale. Paris: La Découverte/Poche.

. (2010b), "Néoliberalisme et subjectivation capitaliste”, Cités nr. 41. Paris: PUF.

(2010c) «Le retour de la guerre sociale». Carré

Rouge.

DEJOURS, Christoph. (2009), Entrevista dada a Jean-Michel Carré para o seu filme J'ai (très) mal au travail (DVD, Éditions Montparnasse).

(1987), Le corps entre biologie et psychanalyse. Paris: Payot.

, (1998), Souffrance en France: la banalisation de l'injustice sociale, Paris: Seuil.

DORAY, Bernard. (1981), Le taylorisme, une folie rationnelle? Paris: Dunod.

FOUCAULT, Michel. (2004), Sécurité, territoire, popula- 
tion. Paris: Gallimard/Seuil.

GELLATELY, Robert. (2001) Backing Hitler: Consent and Coercion in Nazi Germany. Oxford University.

HILBERG, Raul. (2006), La destruction des juifs d'Europe. Paris : Gallimard, Folio/Histoire, 3 vols.

HONNETH, Axel. (1993), The Critique of Power, Cambridge: The MIT Press.

HUGHES, Everett C. (1962), "Good People and Dirty Work” Social Problems, verão de 1962.

KERSHAW, Ian. (2010), Hitler. São Paulo: Cia das Letras.

LE GOFF, Jean-Pierre. (1992), Le mythe de l'entreprise. Paris: La Découverte

LEVI, Primo. (1980), Os afogados e os sobreviventes, trad de Luis Sérgio Henriques. Rio de Janeiro: Paz e Terra.

LINHART, Danièle. (2010), "Métro, boulot, tombeau", Le Monde Diplomatique, novembro 2010.

MOORE JR.,Barrington. (1987), Injustiça: as bases sociais da obediência e da revolta. São Paulo: Brasiliense.

PAXTON, Robert. (2007), A anatomia do fascismo. São Paulo: Paz e Terra.

RENAULT, Emmanuel. (2008), Souffrances sociales. Paris: La Découvert.
SCHEUERMAN, William. (1994), Between the Norm and the Exception. Cambridge: The MIT Press.

TORRENTE, JOSEPH. (1999), “Travail et banalité du mal”, in Revue d'histoire de la Shoah (n. 175).

WIEVIORKA, Michel.(2006), La violence.Paris: Hachette.

ZIZEK, Slavoj. (2003), Bem-vindo ao deserto do real. São Paulo: Boitempo. . (2005), Às portas da Revolução. São Paulo:

Boitempo.

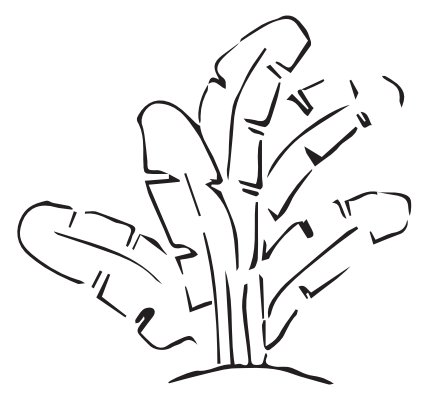

Este livro foi composto nas fontes Literata e Work Sans em novembro de 2021. 